Article

\title{
Forest Cover Changes in Tropical South and Central America from 1990 to 2005 and Related Carbon Emissions and Removals
}

\author{
Hugh D. Eva ${ }^{1}$, Frédéric Achard ${ }^{1}{ }^{1}$, René Beuchle ${ }^{1}$, Evaristo de Miranda ${ }^{2}$, Silvia Carboni ${ }^{3}$, \\ Roman Seliger $^{3}$, Michael Vollmar ${ }^{1}$, Wilson A. Holler ${ }^{2}$, Osvaldo T. Oshiro ${ }^{2}$, \\ Victor Barrena Arroyo ${ }^{4}$ and Javier Gallego ${ }^{1}$
}

1 Institute for Environment and Sustainability, Joint Research Centre (JRC) of the European Commission, I-21027 Ispra, Italy; E-Mails: hugh.eva@jrc.ec.europa.eu (H.D.E.);

rene.beuchle@jrc.ec.europa.eu (R.B.); michael.vollmar@jrc.ec.europa.eu (M.V.);

javier.gallego@jrc.ec.europa.eu (J.G.)

2 Empresa Brasileira de Pesquisa Agropecuária, Monitoramento por Satélite (EMBRAPA-CNPM), Campinas, SP CEP 13070-115, Brazil; E-Mails:mir@cnpm.embrapa.br (E.M.); holler@cnpm.embrapa.br (W.A.H.); osvaldo@cnpm.embrapa.br (O.T.O.)

3 Engineering Ingegneria Informatica S.P.A., Institute for Environment and Sustainability, Joint Research Centre of the European Commission, I-21027 Ispra, Italy;

E-Mails: silvia.carboni@ext.jrc.ec.europa.eu (S.C.); roman.seliger@ext.jrc.ec.europa.eu (R.S.)

4 Laboratorio de Teledetección Aplicada y SIG, Facultad de Ciencias Forestales, Universidad Nacional Agraria La Molina, Lima 100, Peru; E-Mail: vbarrena@lamolina.edu.pe

* Author to whom correspondence should be addressed; E-Mail: frederic.achard@jrc.ec.europa.eu; Tel.: +39-033-2785-545.

Received: 21 March 2012; in revised form: 24 April 2012 / Accepted: 26 April 2012 / Published: 11 May 2012

\begin{abstract}
This paper outlines the methods and results for monitoring forest change and resulting carbon emissions for the 1990-2000 and 200-2005 periods carried out over tropical Central and South America. To produce our forest change estimates we used a systematic sample of medium resolution satellite data processed to forest change maps covering 1230 sites of $20 \mathrm{~km}$ by $20 \mathrm{~km}$, each located at the degree confluence. Biomass data were spatially associated to each individual sample site so that annual carbon emissions could be estimated. For our study area we estimate that forest cover in the study area had fallen from 763 Mha (s.e. 10 Mha) in 1990 to 715 Mha (s.e. 10 Mha) in 2005. During the same period other wooded land (i.e., non-forest woody vegetation) had fallen from $191 \mathrm{Mha}$ (s.e. 5.5 Mha) to $184 \mathrm{Mha}$ (s.e. 5.5 Mha). This equates to an annual gross
\end{abstract}


loss of $3.74 \mathrm{Mha}^{-1}$ of forests $(0.50 \%$ annually) between 1990 and 2000 , rising to $4.40 \mathrm{Mha}^{-1}{ }^{-1}$ in the early $2000 \mathrm{~s}(0.61 \%$ annually), with Brazil accounting for $69 \%$ of the total losses. The annual carbon emissions from the combined loss of forests and other wooded land were calculated to be $482 \mathrm{MtC} \cdot \mathrm{y}^{-1}$ (s.e. $29 \mathrm{MtC} \cdot \mathrm{y}^{-1}$ ) for the $1990 \mathrm{~s}$, and $583 \mathrm{MtC} \cdot \mathrm{y}^{-1}$ (s.e. $48 \mathrm{MtC} \cdot \mathrm{y}^{-1}$ ) for the 2000 to 2005 period. Our maximum estimate of sinks from forest regrowth in tropical South America is $92 \mathrm{MtC} \cdot \mathrm{y}^{-1}$. These estimates of gross emissions correspond well with the national estimates reported by Brazil, however, they are less than half of those reported in a recent study based on the FAO country statistics, highlighting the need for continued research in this area.

Keywords: carbon emissions; deforestation; tropics; remote sensing; monitoring

\section{Introduction}

In spite of the importance of the world's humid tropical forests our knowledge concerning their rates of change and resulting greenhouse gas emissions remains limited with high uncertainties [1,2]. There is, however, evidence of major losses since the 1980s [3-5], with the South American continent thought to be contributing around half of the area of the global gross deforestation [6].

The impact of these changes through carbon emissions to the atmosphere needs to be assessed with more certainty, for which spatially specific data are required. As a result of international concerns, a mechanism has been discussed within the United Nations Framework Convention on Climate Change (UNFCCC), to encourage the reduction of forest clearance in the tropics. To be successful this mechanism-REDD+ (Reduction of Emissions from Deforestation and Forest Degradation in Developing countries)-will require robust repeatable assessments of forest cover changes so as to ensure that real reductions of carbon emissions are taking place $[7,8]$. The objective of the European Commission Joint Research Centre's TREES project is to develop methods to reduce the uncertainties in measuring both forest changes and the ensuing emissions from such changes, thus providing supporting methods for the REDD+ mechanism [9]. This paper outlines the methods and results carried out by the project over tropical Central and South America and the Caribbean for monitoring forest change between 1990, 2000 and 2005. Similar work is being carried out over sub-Saharan Africa and on Southeast Asia [10]. These data are being provided to the United Nations Food and Agricultural Organization (FAO) as a contribution to their Global Forest Resource Assessment 2010 (FRA-2010) Remote Sensing Survey (RSS) [11]. Unlike global surveys, which produce aggregate tables from national data [6], the results of this remote sensing survey provide spatially specific data distributed across the whole study area.

Baseline assessments of forest cover change from remote sensing are undertaken at the national level by a number of countries in the study area, the most extensive being the annual assessment for the Brazilian Legal Amazon [12]. However, no consistent methodology is applied at the regional level, with countries using different data sources, methods and reference years. The current uncertainty in net carbon fluxes from tropical land use change is thought to be as high as $50 \%[2,13]$.

Our study aims to provide a regional assessment of forest cover change and subsequent Carbon 
emissions during the 1990s and early 2000s. It covers the land surface area of all the countries of tropical South America (we do not cover the southern cone countries of Argentina, Chile and Uruguay) and the Central American countries up to and including Belize, along with the Caribbean islands. Estimating deforestation at such extensive levels would be a major challenge without the use of satellite imagery, in particular for remote regions. Technical capabilities and statistical tools have advanced since the early 1990s [14] and operational forest monitoring systems at the national level are now a feasible goal for most developing countries in the tropics [15,16]. For our survey we used a systematic sampling grid with sample units $(20 \mathrm{~km}$ by $20 \mathrm{~km}$ for the 1990 's reduced to $10 \mathrm{~km}$ by $10 \mathrm{~km}$ for the 2000-2005 period) located at the degree confluence, that is the point where an integer degree of latitude and an integer degree of longitude meet (e.g., $63^{\circ} 00^{\prime} 00^{\prime \prime} \mathrm{N}, 34^{\circ} 00^{\prime} 00^{\prime \prime} \mathrm{W}$ ). At each of these sample locations satellite data (Landsat Thematic Mapper) with medium spatial ground resolution $(30 \mathrm{~m} \times 30 \mathrm{~m})$ were acquired as close as possible to the reference years of 1990, 2000 and 2005 (Figure 1). These data were processed so as to produce forest change statistics at regional levels by statistical expansion.

Figure 1. The study area with the location of the 1,230 sample sites. The location of the sites shown in Figure 2 are shown in red.

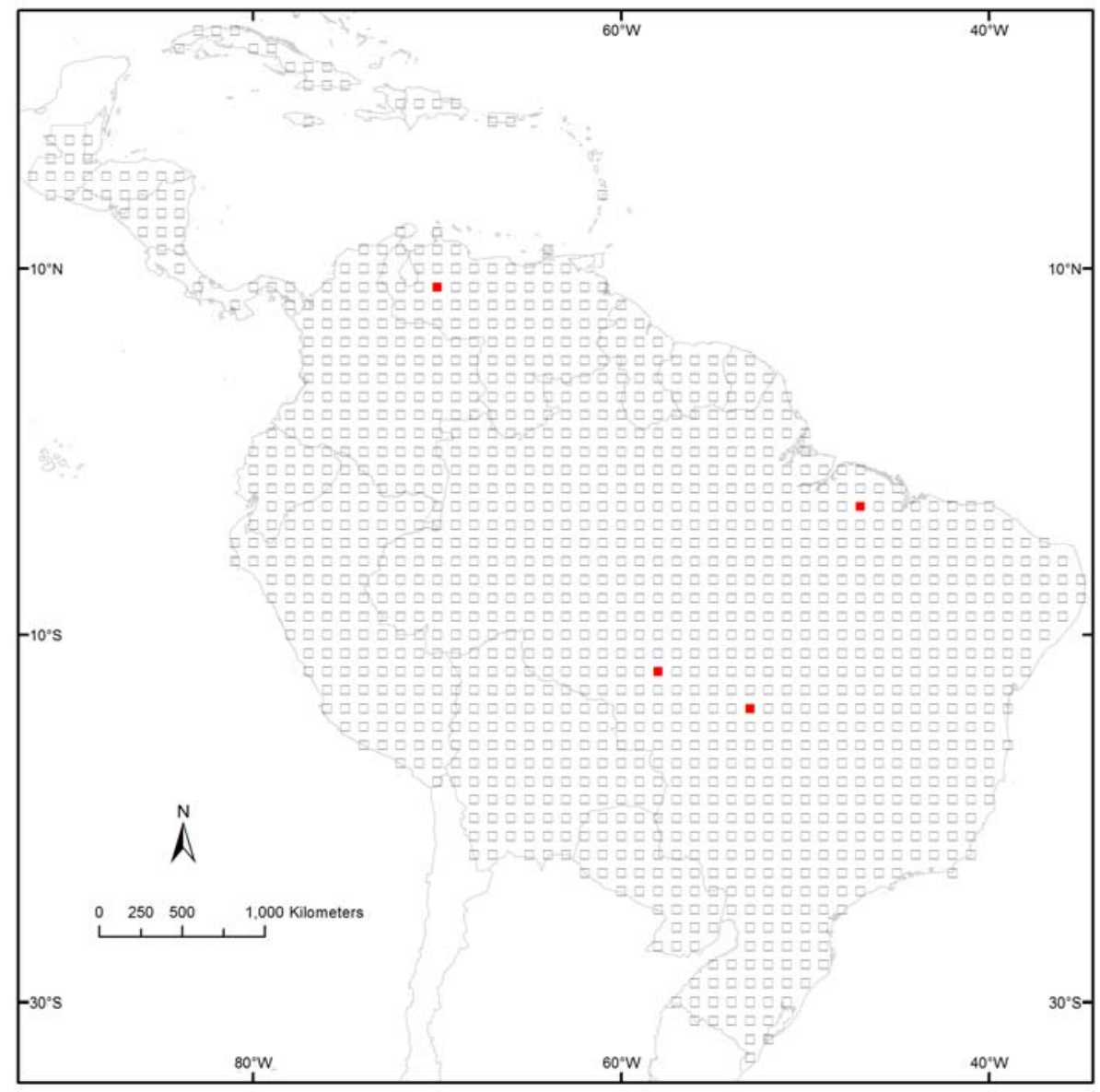


Figure 2. (a) Landsat satellite imagery $(20 \mathrm{~km} \times 20 \mathrm{~km}$ box size $)$ at $30 \mathrm{~m}$ resolution with the $10 \mathrm{~km} \times 10 \mathrm{~km}$ box highlighted in red; (b) Classification results obtained for the four example sample sites $(10 \mathrm{~km} \times 10 \mathrm{~km}$ size $)$.
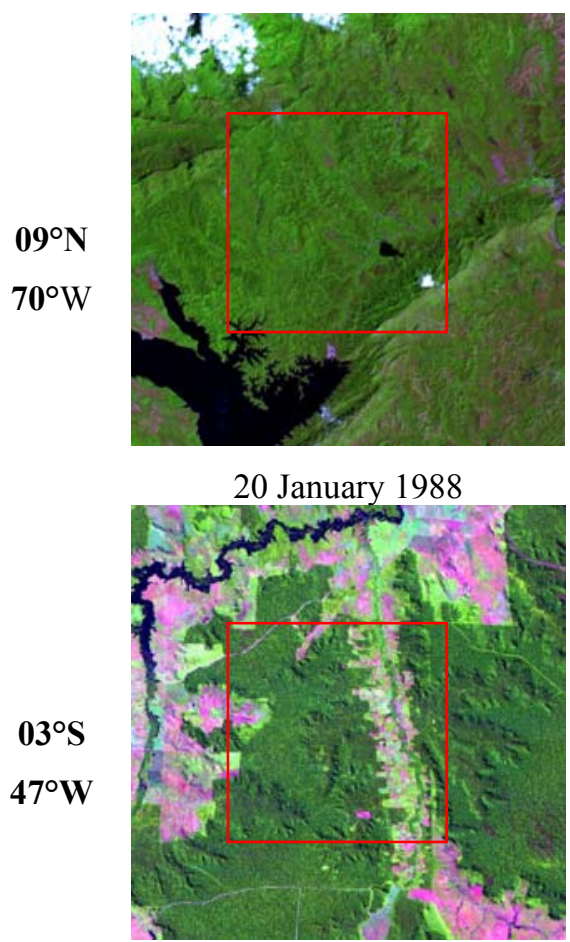

24 July 1991

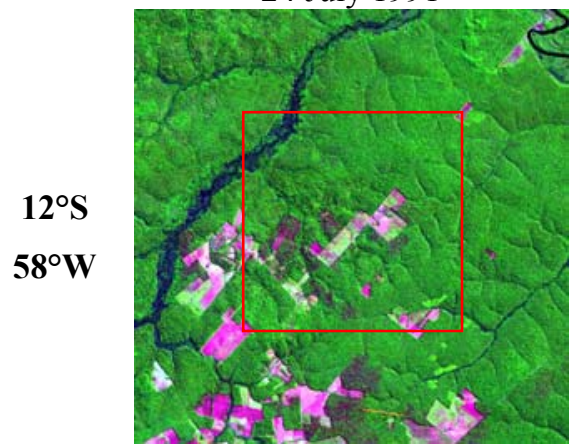

10 July 1994

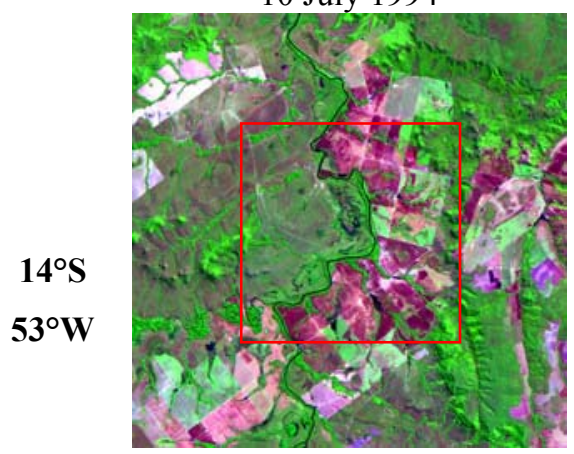

21 June 1989

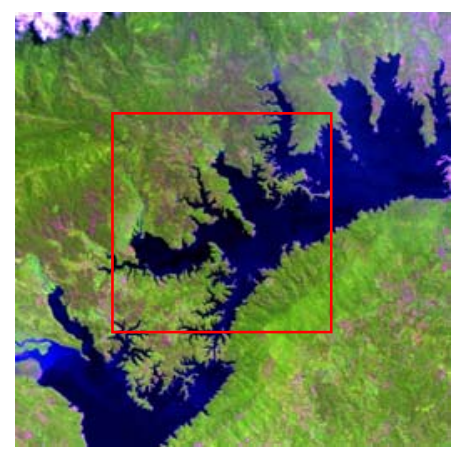

16 June 2001

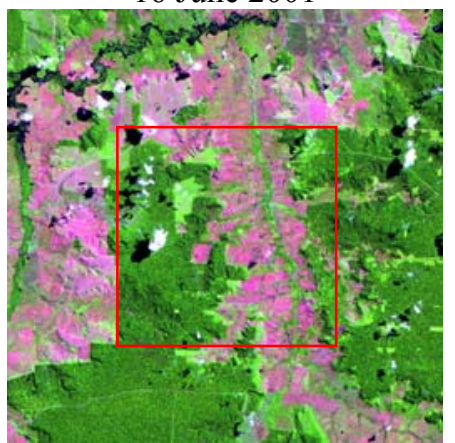

04 August 2001

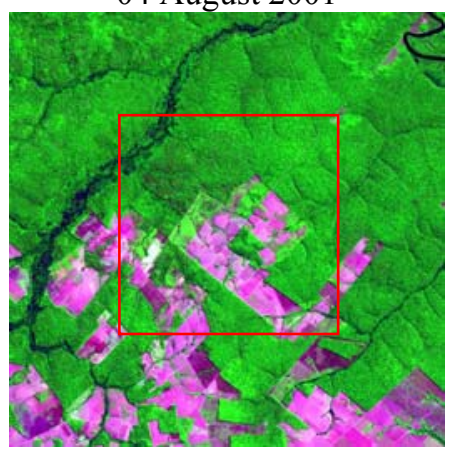

06 August 2001

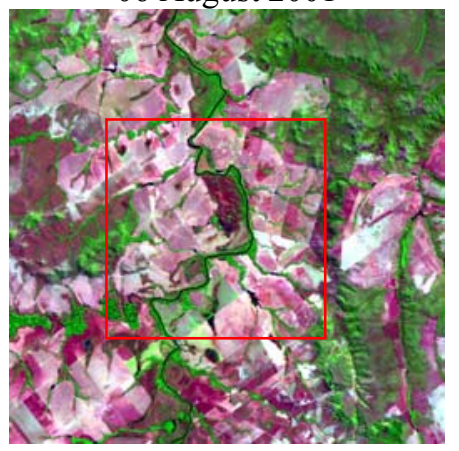

29 July 2000

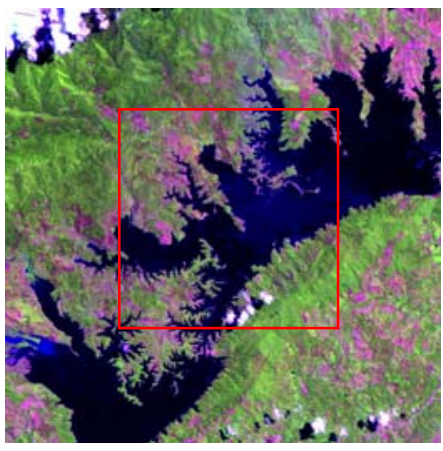

11 June 2008

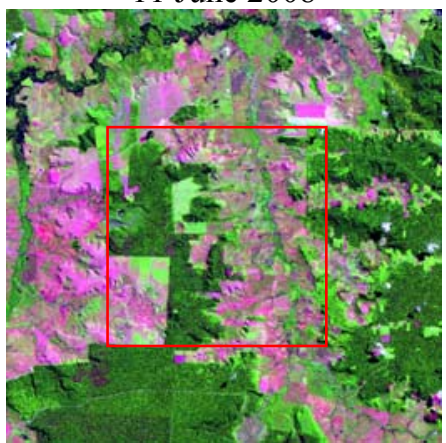

14 July 2005

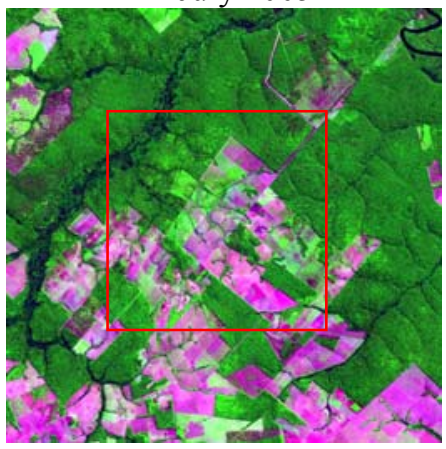

14 June 2005

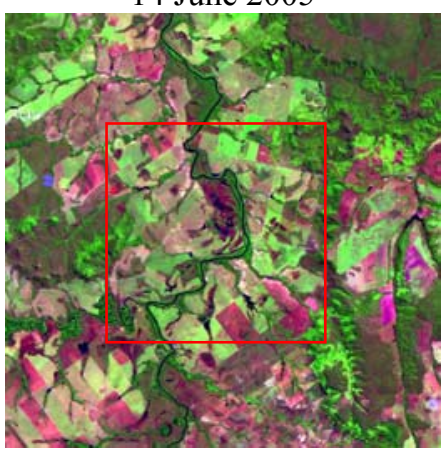

14 May 2006

(a) 
Figure 2. Cont.

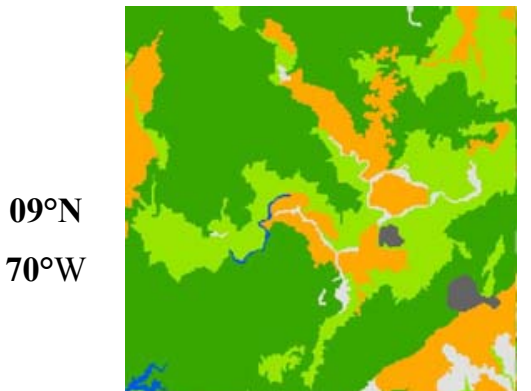

20 January 1988

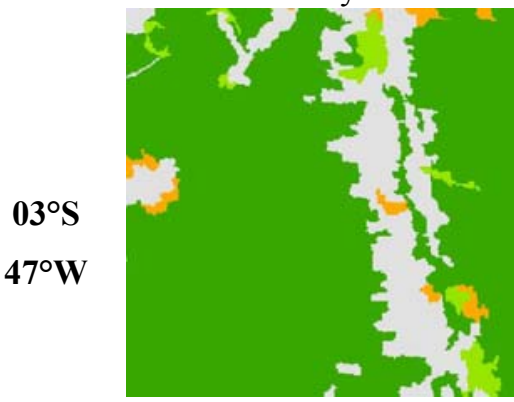

24 July 1991
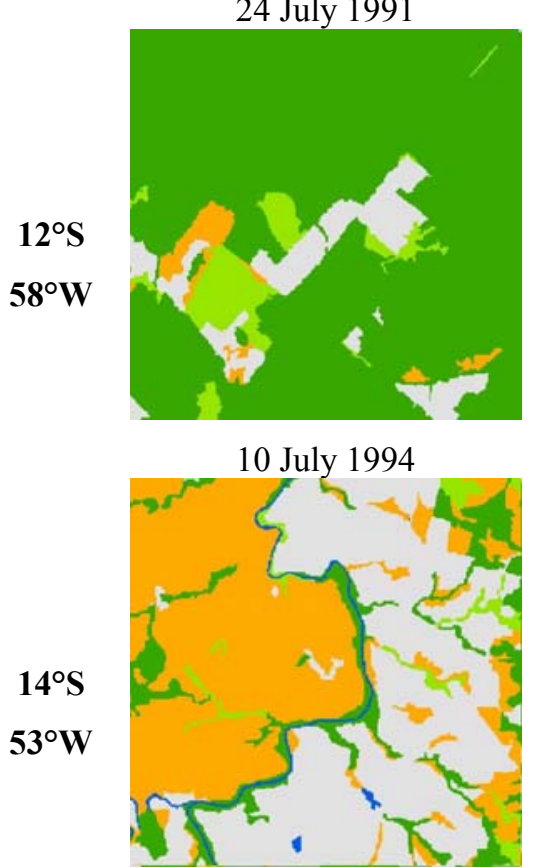

21 June 1989
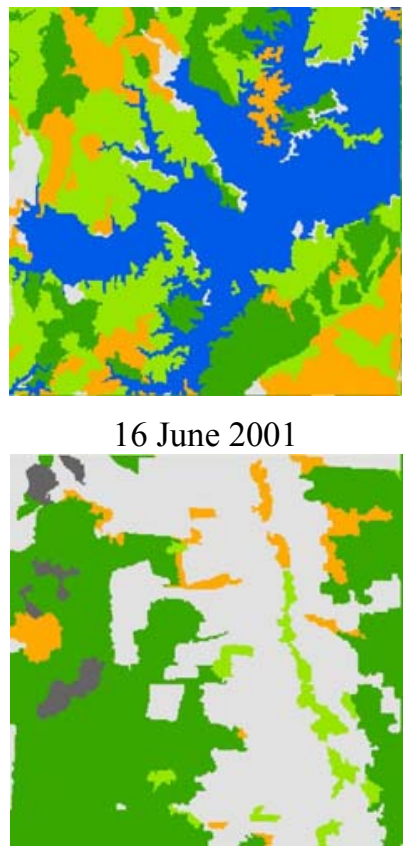

04 August 2001

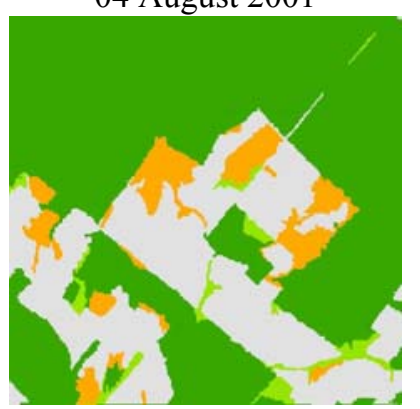

06 August 2001

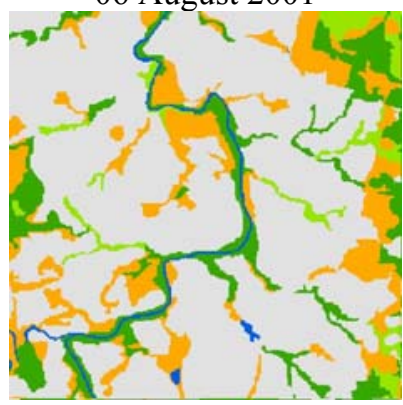

29 July 2000
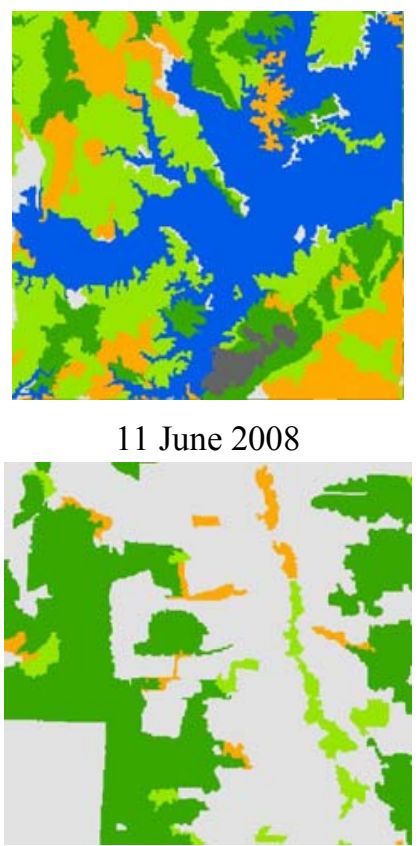

14 July 2005

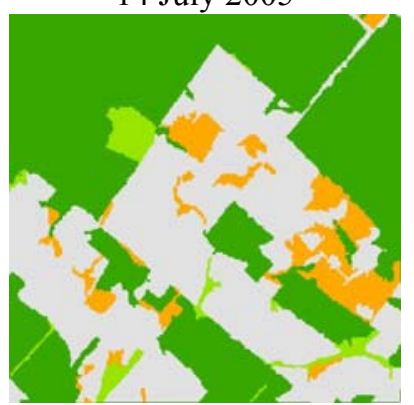

14 June 2005

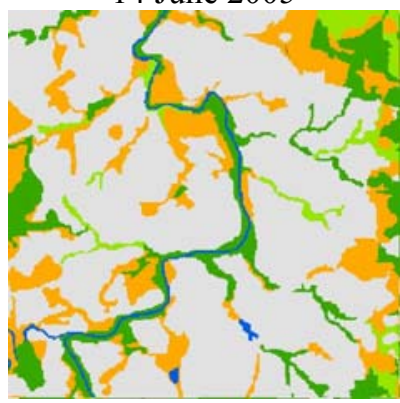

14 May 2006

(b)

The FAO definition of 'forest' is those areas of at least 0.5 ha size with tree canopy density greater than $10 \%$ and tree height greater than $5 \mathrm{~m}$. However, these thresholds cannot be 'measured' from medium spatial resolution Landsat satellite imagery with high accuracy. A more feasible assessment is that the canopy density is greater than $30 \%$. This mismatch can lead to an underestimation of forest areas from the Landsat data when compared to field based inventories using the FAO definition. At the 7th Conference of the Parties (COP-7) under the "Marrakesh accords" the UNFCCC adopted a forest definition with a degree of flexibility. For land use, land-use change and forestry activities under Article 3, paragraphs 3 and 4 of the Kyoto Protocol, the following definition shall apply: "Forest" is a 
minimum area of land of 0.05-1.0 ha with tree canopy cover of more than 10-30 percent (trees being those with the potential to reach a minimum height of 2-5 $\mathrm{m}$ at maturity in situ). To date, most countries are defining forests with a minimum crown cover of $30 \%$, which is more compatible with medium resolution satellite imagery. In our study we accept that the $30 \%$ threshold for the detection of forest cover is the pragmatic limit of the data source. Land use (hence unstocked forest land) is not addressed. In this study we produce area and area change statistics for two 'forest' classes, tree cover (assumed to be 100\% forest) and tree cover mosaic (assumed to be 50\% forest). These have been mapped at a landscape scale using a 5 ha minimum mapping unit, aggregated from smaller, homogenous units of 1 ha. The aggregation was undertaken so that a visual verification (and possible editing for corrections) could be feasibly carried out (details are given in the experimental section). Three other non-forest classes are mapped.

\section{Experimental Section}

A sampling scheme was used (as opposed to wall-to-wall coverage) so as to reduce data processing and to link to existing national surveys [17] (see: www.fao.org/forestry/nfms). The potential to intensify the sampling grid to obtain territorial estimates has already been demonstrated over French Guiana [18]. The sample grid provides 1,230 sample units each initially of $20 \mathrm{~km}$ by $20 \mathrm{~km}$, uniformly distributed across the study area. Unlike previous surveys, which targeted only the forest domain, the entire land surface was covered by the study.

While in our previous survey [3] a stratification was used, the operational need to revisit the same sites, and the lack of good wall-to-wall data for a regression estimator over the first reference period (1990-2000) means that neither stratification nor regression estimation have been employed in the current study. Where available such data have been shown to bring about advantages [19].

\subsection{Satellite Imagery Acquisition and Pre-Processing}

For each sample location the available Landsat Thematic Mapper (TM) and Enhanced Thematic Mapper (ETM) data were sought from the Global Land Survey (GLS) database, freely available from the Earth Resources Observation Systems (EROS) Data Center (EDC) of the US Geological Survey (USGS).The GLS data have the advantage over the previous GeoCover dataset of higher geo-location accuracy with terrain correction being carried out with an improved digital elevation data at a $90 \mathrm{~m}$ resolution from the Shuttle Radar Topography Mission (SRTM) [20]. The data were downloaded at full resolution $(30 \times 30 \mathrm{~m})$. The $20 \mathrm{~km} \times 20 \mathrm{~km}$ imagettes (in UTM projection) covering the sample sites were extracted and visually screened (see Figure 2(a)). In the event of the data being unacceptable (due to cloud cover or artifacts) replacement data were sought from the Brazilian Space Agency, INPE (Instituto Nacional de Pesquisas Espaciais) with the help of the GEOSS (Global Earth Observing System of Systems) Land Surface Imaging Constellation (LSI). For the 1,230 samples sites covering the study area, 1,222 good image pairs were found for 1990-2000 and 1130 good pairs for 2000-2005. The missing sites were located in Central America, the Colombian Choco, the Central Amazon region and in the Guianas. The higher number of missing sites in the second period assessed (2000-2005) is due to the malfunctioning of the line scanner on the Landsat 7 ETM+ sensor after 1 June 2003, which results in the corruption of around two thirds of the image, thus severely reducing the amount 
of exploitable imagery. A full review of the available images and acquisition dates is given in Beuchlé et al. [21].

For each sample site, the satellite imagettes (from 1990, 2000 and 2005) were preprocessed for geometric control, radiometric calibration and normalization, segmentation and finally classification. The steps in satellite image preprocessing are described in detail in Bodart et al. [22]. An automatic check was made on the geometric matching between images using image correlation. The data were corrected to top of atmosphere reflectance and then the images were radiometrically normalized to each other using the dark object subtraction, in this case evergreen forest [23]. In this way differences in reflectance of a given surface due to haze or calibration issues between image dates were reduced [24]. Where no evergreen forest was present in a site a relative normalization was used, with an operator identifying a suitable radiometrically stable area in the site. The imagette from the year 2000 was taken as the reference for geometric and radiometric controls.

\subsection{Image Classification}

After pre-processing the imagettes were segmented so as to produce homogenous land units (segments) which could then be classified for each date [24]. The segmentation process was initially implemented on two-date imagery (1990 and 2000) in a single operation so as to ensure a coherence of segments in the two dates. The calibrated TM and/or ETM+ bands 3, 4 and 5 were used together with equal weights for all bands. An initial minimum mapping unit of 1 ha was set for the segments. This was a compromise between not having a large number of very small segments and avoiding segments with mixed land covers, which would create problems for a classifier. The segments from the individual imagettes were then classified using a supervised classification. In a second phase, these classified segments were aggregated into 5 ha segments so as to enable a feasible visual assessment of the classification by local experts.

For the first level classification at $1 \mathrm{ha}$, membership functions for the supervised classifier were generated from a spectral library of over one hundred homogeneous spectral classes. These were obtained by an interpreter collecting spectral signatures for existing land cover types from a systematic sub-sample of the imagettes [24]. A large number of spectral classes are required to cover the variability of spectral reflectance within any particular land cover class, e.g., the "tree cover" class consists of 15 spectral classes ranging from coniferous forests to mangrove forests to deciduous forests in different phenological phases. The 1 ha size classified segments, in theory composing of $100 \%$ pure cover, were automatically aggregated to a 5 ha level (see Figure 2(b)) into a few broad land cover classes based on the proportion of tree cover within segments: (i) 'Tree Cover' class with more that $70 \% 1$ ha level tree cover within the 5 ha segment; (ii) 'Tree Cover Mosaic' class with 30 to $70 \% 1$ ha level tree cover within the 5 ha segment, and three other non-forest classes with less than $30 \%$ tree cover; (iii) 'Other Wooded Land' (iv) 'Water' and (v) 'Other Land Cover'. The term 'Other Wooded Land' is used for describing any woody vegetation layer (shrubs) of less than $5 \mathrm{~m}$ height. For segments with a tree cover portion of less than $30 \%$, a minimum proportion $(70 \%)$ of a specific land cover (e.g., $\geq 70 \%$ 'Other Wooded Land') was required, otherwise the segment was assigned to the 'Other Land Cover'. The 'Other Land Cover' class groups together all non-woody vegetation land cover classes, with the exception of 'Inland Water'. 
Every single resulting classification from 1990-2000 was then inter-dependently visually controlled internally by the project staff. This was followed by an independent verification of these 1,222 change maps by national experts from forest and remote sensing institutes from the countries covered by the study. Where classification errors were found they were corrected. Once these two-date classifications were controlled and corrected the third date (2005) was segmented and classified using the year 2000 classification as a template for class labeling of year 2005. An inter-dependent visual control and correction was then made for the classifications of the 2000-2005 period.

\subsection{Extrapolation of Results}

It was not possible to find images corresponding to the exact reference dates for all sites. Images were acquired within a range from 1984 to 1992 for the first reference year (1990), 1997 to 2003 for the second reference year (2000) and 2004 to 2009 for the third reference year (2005) [21]. Each sample site's area estimate was then adjusted to the baseline dates of 30 June 1990, 2000 and 2005: this was done by assuming that the land cover changes are constant during the given period (in the absence of some ancillary data at the regional level we cannot provide any other model). We therefore linearly adjusted the land cover change matrices to the reference dates/years. Cloudy areas within a sample site were considered as unbiased data loss, and were assumed to have the same proportions of land cover as the non-cloudy areas in the same site. This was achieved by converting the land cover change matrices for 1990-2000 and 2000-2005 to area proportions relative to the total land area of the sample site without clouds. It resulted in proportions matrices totaling 1 for the sum of their $5 \times 5$ elements.

For the missing sample sites (nine in the first period 1990-2000 and 110 in the second period 2000-2005) we used a local average from the surrounding 8 sample sites as surrogate results — with the hypothesis that surrounding sample sites are more representative of missing sample sites than the full available population. The following weights were applied for the local average of missing sites:

$$
\delta_{i j^{\prime}}=1 / d\left(j, j^{\prime}\right)=1 /(\operatorname{dif}(\text { lat }))^{4}+(\operatorname{dif}(\text { long }))^{4}
$$

where dif is the distance to the surrounding site involved. Small differences may appear between land cover proportions of year 2000 obtained from the two change matrices (1900-2000) and (2000-2005) due to the linear extrapolation to the reference dates. To correct for potential inconsistencies in estimates at regional level for the common year 2000, for each sample site the land cover proportion change matrix 2000-2005 was 'calibrated' to the land cover proportions of year 2000 from the 1990-2000 matrix by using a linear adjustment.

For the statistical estimation phase the sample sites were weighted in relation to their probability of selection. The sample frame, although systematic, does not have an equal probability of selection for each site due to the location of the confluence points. The circumference of the circle of latitude reduces in proportion to the cosine of the latitude; hence all sample units were given the weighting $w_{i}$, equal to 1 multiplied by the cosine of the latitude to account for the resulting higher spatial sampling frequency away from the equator. As the selected sample sites which contained a proportion of sea were considered as full sites (total of area proportions equal to 1), this compensated for those sample sites that contained a proportion of sea but were not selected as the center of the site- the confluence point - was located in the sea. 
The proportions of land cover changes were then extrapolated to the study area using the Horvitz-Thompson Direct Expansion Estimator [25]. The estimator for each land cover class transition is the mean proportion of that change per sample unit, given by Equation (2):

$$
\bar{y}_{c}=\frac{1}{m} \sum_{i=1}^{n} w_{i} \cdot y_{i c}
$$

where $y_{i c}$ is the proportion of land cover change for a particular class transition ' $c$ ' in the $i^{\text {th }}$ sample unit. The weight of the sample unit is $w_{i}$ and $m$ is the sum of the sample weights. The total area of change for this class transition $\mathrm{Z}_{\mathrm{c}}$ is obtained from:

$$
Z_{c}=D \cdot \bar{y}_{c}
$$

where $D$ is the total area of the study region.

Rather than the usual variance estimation of the mean for systematic sampling [26] we used a local estimation of the variance as follows:

$$
s^{2}=\frac{\sum_{j \neq j^{\prime}} w_{j j^{\prime}} \delta_{j j^{\prime}}\left(y_{j}-y_{j^{\prime}}\right)^{2}}{2 \sum_{j \neq j^{\prime}} w_{j j^{\prime}} \delta_{j j^{\prime}}}
$$

where the weight $w_{j j^{\prime}}$, is an average of the weights $w_{j}$ and $w_{j^{\prime}}$ and $\delta_{j j^{\prime}}$ is a decreasing function of the distance between $j$ and $j^{\prime}$ (Note that if we choose $\delta_{j j^{\prime}}=1 j \neq j^{\prime}$ we obtain the usual variance estimator). For $w_{j j^{\prime}}$ we used a value of 1 (as a simplification because all the weights $w_{j}$ are close to 1 ) and for $\delta_{j j^{\prime}}$ we applied Equation (1) also used for deriving local average of missing sites. The standard error (s.e.) is then calculated as:

$$
s e=\frac{s}{\sqrt{n}}
$$

where $n$ is the total number of available sample sites (i.e., not accounting for the missing sites even if they are replaced by a local average). The standard error represents the precision obtained with our sample scheme. The observations (source data sets) that are used to produce these results are derived from the satellite interpretations. These surrogates to ground observations may be subject to the uncertainty (bias) but we do not address such errors here [27]. Such errors are introduced mainly through misclassification where different land cover classes have similar spectral signatures. The use of such surrogate data for assessing area change is inevitable in many areas of the tropics where no ground observations exist and where large areas of inaccessible forests can only be monitored at affordable costs by the exploitation of satellite data.

\subsection{Independent Analysis of Image Interpretations}

In our previous large-scale assessment using a similar visual inter-dependent interpretation method, we assessed the 'consistency' of the results of the interpretations [3]. The independent image-interpretation "consistency assessment" performed on a sub-sample of the data set resulted in 
some $93 \%$ and $96 \%$ agreement globally and for Latin America respectively for 10 aggregated land cover classes, and to some $91 \%$ and $96 \%$ agreement globally and for Latin America respectively for the forest cover change estimations. In addition to this earlier consistency assessment, we asked the relevant national institution, INPE, to independently visually interpret a random selection of 34 sample sites using our legend over the Brazilian legal Amazon. The comparison between INPE's interpretations and our own shows a good correspondence both for the forest area of year 1990 and deforestation of period 1990-2000 with slopes close to 1 (1.017 and 1.008 respectively) and $R^{2}$ close to 1 ( 0.986 and 0.978 respectively) (Figure 3 ).

Due to the high investment in expert time required to visually control the interpretations we compared the land cover estimates and land cover change estimates derived from the 1990-2000 interpretations in $20 \mathrm{~km}$ by $20 \mathrm{~km}$ boxes with results using only the central $10 \mathrm{~km}$ by $10 \mathrm{~km}$ portion of the same interpretations. The close correspondence between these two estimates (Table 1) enabled us to process and analyse only the central $10 \mathrm{~km}$ by $10 \mathrm{~km}$ portion of the sample sites for the 2000-2005 period, resulting in a substantial savings in time and resources.

Figure 3. Comparison between sites interpreted by the Instituto Nacional de Pesquisas Espaciais (INPE) and by our interpreters: (a) location of the 34 random sample sites; (b) forest cover for year 1990 (in ha); (c) gross deforestation for period 1990-2000 (in ha).

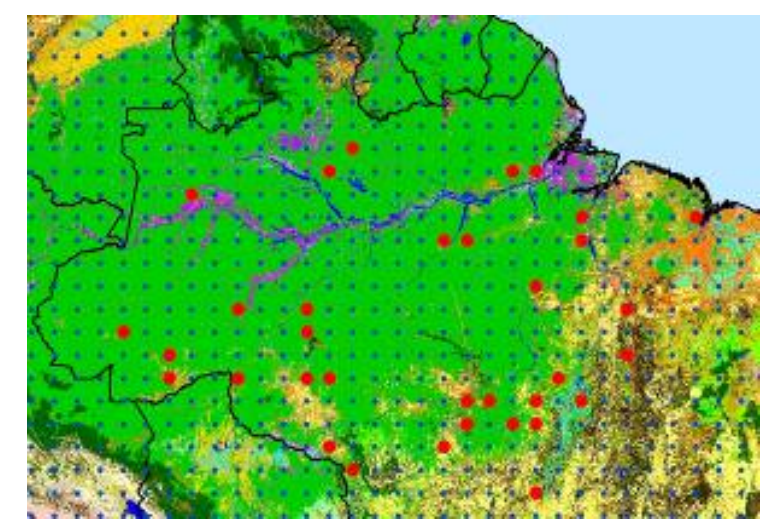

(a)

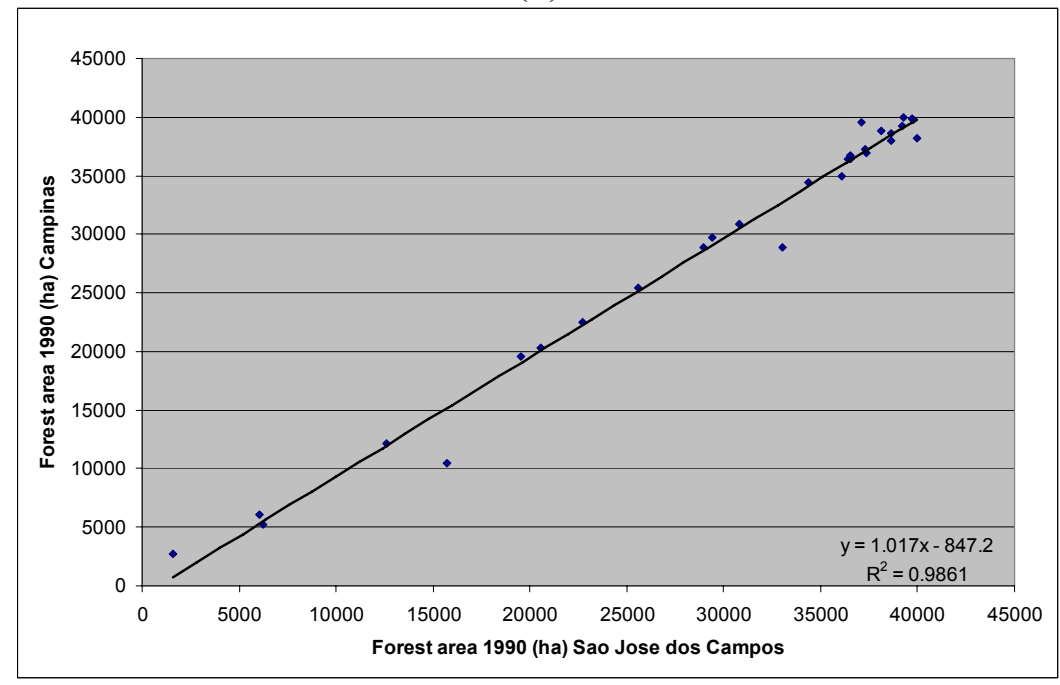

(b) 
Figure 3. Cont.

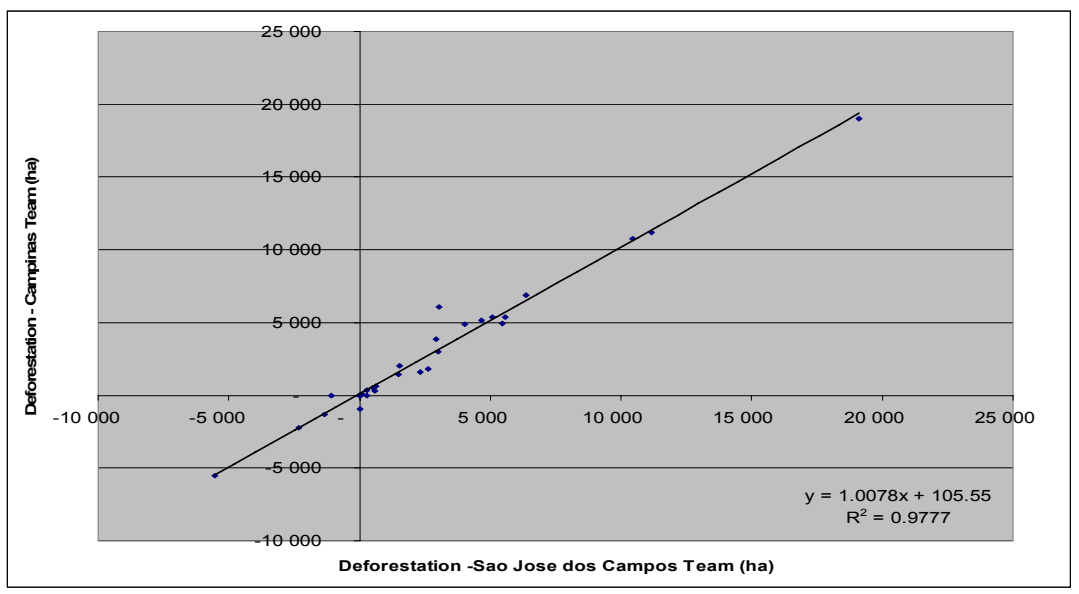

(c)

Table 1. Comparison of land cover estimates for year 1990 for South \& Central America when using $20 \mathrm{~km} \times 20 \mathrm{~km}$ and $10 \mathrm{~km} \times 10 \mathrm{~km}$ sample sites (in $10^{6} \mathrm{ha}$ ).

\begin{tabular}{|c|c|c|c|c|}
\hline $\begin{array}{c}\text { Size of Sample Sites } \\
\text { Land Cover Type }\end{array}$ & $20 \times 20 \mathrm{~km}$ Area & $20 \times 20$ km s.e. & $10 \times 10 \mathrm{~km}$ Area & $10 \times 10 \mathrm{~km}$ s.e. \\
\hline Tree Cover & 727.6 & 8.7 & 731.2 & 9.2 \\
\hline Tree Cover Mosaic & 63.2 & 1.8 & 64.0 & 2.1 \\
\hline Other Wooded Land & 190.9 & 4.9 & 191.2 & 5.4 \\
\hline Other Land Cover & 445.0 & 7.8 & 439.1 & 8.7 \\
\hline Water & 26.2 & 2.9 & 30.1 & 3.2 \\
\hline
\end{tabular}

\subsection{Calculations of Emissions Estimates}

The selection of biomass levels and resulting carbon content for specific regions remains problematic due to lack of consistent data worldwide [28] and has been the source of some debate [29]. To estimate carbon fluxes from the changes in forest cover we created a spatially explicit data set by combining the FAO ecozone map with the Above Ground Biomass (AGB) map for tropical South America derived from maps of basal area and wood density extrapolated from data from over 200 forest plots [30]. The latter gives a gradation of AGB levels over the region, rather than a single figure as often used. The estimates from this map range from 200 to over $350 \mathrm{Mg} \cdot \mathrm{DW} \cdot \mathrm{ha}^{-1} \mathrm{AGB}$, and are on the whole lower than those estimates we used in our previous study. Spatially they show a fall in biomass from $350 \mathrm{t} \cdot \mathrm{ha}^{-1}$ in the Guinas and in the Central Amazonian basin to levels of $200 \mathrm{t} \cdot \mathrm{ha}^{-1}$ in the contact zones in the south and east and in the pre-montane forests of the Andes. The lower biomass in the 'arc of deforestation' is supported by recent direct measurements from [31,32]. Outside this area we associate AGB biomass levels for forests ('Tree cover') and shrubs ('Other wooded land') from the literature to each ecozone. We used IPCC [33] ratio of below-ground biomass to above-ground biomass for conversion to total biomass (ratio ranges from 0.37 for rainforest to 0.24 for sub-tropical humid forests) and we assumed 50\% of biomass to be carbon. We did not account for losses of carbon in soils. The annual carbon emissions for the study area was calculated as the gross committed emissions over a 10 year period arising from one year of forest and woodland clearance [34]. This accounts for $69 \%$ of the total carbon that could be committed [35]. 


\section{Results and Discussion}

\subsection{Forest Area and Area Change Results}

We found that for the year 1990 there were 763 Mha (s.e. 10 Mha) of forest (Table 2(a): tree cover + $50 \%$ tree cover mosaic) in our study area and 191 Mha (s.e. 5.4 Mha) of other wooded land. By 2000 the forest area had fallen to $733 \mathrm{Mha}$ (s.e. $10 \mathrm{Mha}$ ) with $189 \mathrm{Mha}$ (s.e. 5.5 Mha) of other wooded land and by 2005715 Mha (s.e. 10 Mha) of forests and 184 Mha (s.e. 5.5 Mha) of other wooded land. Comparisons with other estimates (Table 3) show a high variation between the different studies. Our forest area estimate is substantially less than the most recent FAO estimate for year 2000 of 877 Mha derived from the country survey of the Global Forest Resources Assessment 2010 (FRA 2010) [6], but FAO is using a land use definition of forests with $10 \%$ tree cover threshold. The limitations of the FAO country surveys are known, in particular due the lack of reliable figures for some countries and the difficulty to harmonize national definitions and estimates [1]. FAO reports forest cover for Brazil for year 2000 of 546 Mha which corresponds well to the sum of our year 2000 forest and other wooded land estimates for Brazil (derived from 808 sample units) of 542 Mha (406 Mha of forests and 136 Mha of other wooded land). The land cover map of South America for the year 2000 [36] gives a higher figure of 786 Mha for the forest area, but this map is also based on coarse resolution, $1 \mathrm{~km}$, satellite imagery which are not considered appropriate to estimate with accuracy land cover areas and their changes [17]. Our previous study, TREES-II [3], reported an estimate of 647 Mha for tropical humid forests of Central and South America which would lead to a forest cover estimate of 727 Mha when corrected for Mexico and dry tropical forests of South America. This figure (727 Mha) is very close to our current study estimate (733 Mha). Our forest area estimate for year 2000 lies between the FAO estimate from the previous remote sensing survey of FRA 2000 (based on a lower intensity sample of Landsat satellite imagery) of 700 Mha [37] when adjusted for Mexico and the estimate from another remote sensing based study (based on coarse resolution-500 m-satellite imagery) at 814 Mha [4] when adjusted for the countries outside our study (Argentina, Chile and Uruguay). The circa 10\% difference between our estimates (TREES-II and present study at 727 and $733 \mathrm{Mha}$ ) and the two other remote sensing based estimates for the same region (at 700 and 814 Mha) points to the remaining difficulties in comparing estimates from different data sources, methodologies and more importantly with different forest definitions. This comparison at regional scales indicates that a large proportion of our other wooded land class is considered as 'forest' by the other remote sensing based surveys.

To assess if our results are consistent with other assessments, we compared our forest area estimate for the Brazilian Legal Amazon region (derived from the 411 sample units covering this region) to an independent estimate from a wall to wall assessment using the same type of imagery. The Landsat Pathfinder forest estimate of Brazilian Amazonia of year 1988 [38] corrected to year 1990 leads to a rain forest area at 361.3 Mha which is $7.2 \%$ lower than the estimate of our study at 389.3 Mha (s.e. 5.6 Mha). However the Landsat Pathfinder estimate does not include the dry forests of Brazilian Amazonia (cerrado) which are considered to represent circa 10 percent of the total forest area [39]. Our previous TREES-II [3] led an estimate of tropical humid forests for Brazilian Amazonia at 381.9 Mha for 1990, a 1.9\% difference with our new 1990 estimate. We consider therefore our present study estimate as a consistent estimate of total forest area of Brazilian Amazonia. 
Table 2. (a) Land cover change matrices for the whole study area 1990-2000; (b) and for 2000-2005. All values in $10^{6}$ ha.

\begin{tabular}{|c|c|c|c|c|c|c|c|c|c|c|c|c|}
\hline \multirow[t]{2}{*}{$\begin{array}{l}2000 / \\
1990\end{array}$} & \multicolumn{2}{|c|}{ Tree Cover } & \multicolumn{2}{|c|}{$\begin{array}{c}\text { Tree Cover } \\
\text { Mosaic } \\
\text { (TCM) } \\
\end{array}$} & \multicolumn{2}{|c|}{$\begin{array}{c}\text { Other Wooded } \\
\text { Land } \\
\text { (OWL) }\end{array}$} & \multicolumn{2}{|c|}{$\begin{array}{c}\text { Other Land } \\
\text { Cover } \\
\text { (OLC) } \\
\end{array}$} & \multicolumn{2}{|c|}{ Water } & \multicolumn{2}{|c|}{ Total 1990} \\
\hline & area & s.e. & area & s.e. & area & s.e. & area & s.e. & area & s.e. & area & s.e. \\
\hline $\begin{array}{l}\text { Tree } \\
\text { Cover }\end{array}$ & 693,900 & 9,100 & 8,200 & 600 & 5,900 & 400 & 22,400 & 1,700 & 700 & 300 & 731,200 & 9,200 \\
\hline TCM & 3,500 & 200 & 52,000 & 1,900 & 3,200 & 200 & 5,000 & 300 & 400 & 200 & 64,000 & 2,100 \\
\hline OWL & 2,100 & 500 & 2,500 & 200 & 166,500 & 5,200 & 19,800 & 1,000 & 300 & 100 & 191,200 & 5,400 \\
\hline OLC & 1,600 & 200 & 1,500 & 100 & 13,400 & 800 & 421,700 & 8,300 & 900 & 200 & 439,100 & 8,700 \\
\hline Water & 100 & 0 & 100 & 100 & 200 & 100 & 1,200 & 200 & 25,900 & 3,000 & 27,500 & 2,100 \\
\hline $\begin{array}{l}\text { Total } \\
2000 \\
\end{array}$ & 701,200 & 9,200 & 64,300 & 2,100 & 189,300 & 5,300 & 470,100 & 9,300 & 28,100 & 3,200 & $1,453,000$ & \\
\hline \multicolumn{13}{|c|}{ (a) } \\
\hline $\begin{array}{l}2005 / \\
2000\end{array}$ & Tree C & over & \multicolumn{2}{|c|}{$\begin{array}{c}\text { Tree Cover } \\
\text { Mosaic } \\
\text { (TCM) }\end{array}$} & \multicolumn{2}{|c|}{$\begin{array}{l}\text { Other Wooded } \\
\text { Land (OWL) }\end{array}$} & \multicolumn{2}{|c|}{$\begin{array}{c}\text { Other Land } \\
\text { Cover (OLC) }\end{array}$} & \multicolumn{2}{|c|}{ Water } & \multicolumn{2}{|c|}{ Total 2000} \\
\hline & area & s.e. & area & s.e. & area & s.e. & area & s.e. & area & s.e. & area & s.e. \\
\hline $\begin{array}{l}\text { Tree } \\
\text { Cover }\end{array}$ & 678,900 & 9,500 & 4,900 & 400 & 4,100 & 400 & 13,000 & 1,200 & 300 & 100 & 701,200 & 9,600 \\
\hline TCM & 2,000 & 300 & 58,000 & 2,100 & 1,500 & 200 & 2,600 & 200 & 200 & 100 & 64,200 & 2,200 \\
\hline OWL & 1,100 & 200 & 1,300 & 400 & 172,300 & 5,600 & 14,200 & 1,700 & 400 & 200 & 189,200 & 5,600 \\
\hline OLC & 400 & 100 & 400 & 100 & 6,000 & 600 & 462,300 & 9,000 & 900 & 200 & 470,000 & 9,100 \\
\hline Water & 0 & 0 & 0 & 0 & 0 & 0 & 1,300 & 300 & 26,700 & 3,200 & 28,100 & 3,300 \\
\hline $\begin{array}{l}\text { Total } \\
2005 \\
\end{array}$ & 682,400 & 9,600 & 64,500 & 2,200 & 184,000 & 5,600 & 493,400 & 9,600 & 28,500 & 3,400 & $1,452,800$ & \\
\hline
\end{tabular}

(b)

Table 3. Tropical forest cover estimates for (i) South \& Central America region for year 2000 and (ii) Brazilian Legal Amazon for year 1990 from different sources_-from oldest to most recent publication date (in $10^{6} \mathrm{ha}$ ).

\begin{tabular}{ccccccc}
\hline $\begin{array}{c}\text { Source } \\
\text { Forest cover }\end{array}$ & $\begin{array}{c}\text { Landsat } \\
\text { Pathfinder }\end{array}$ & $\begin{array}{c}\text { FAO } \\
\text { FRA-2000 } \\
\text { RSS }\end{array}$ & TREES-II & SDSU & $\begin{array}{c}\text { FAO } \\
\text { FRA-2010 } \\
\text { CS }\end{array}$ & This study \\
\hline $\begin{array}{c}\text { Central and } \\
\text { South America } \\
\text { (for year 2000) }\end{array}$ & 700.4 & 726.8 & 814.3 & 883.6 & 733.3 (se 10.3) \\
$\begin{array}{c}\text { Legal Amazon } \\
\text { (for year 1990) }\end{array}$ & 361.3 & & 381.9 & & & 389.3 (se 5.4) \\
\hline
\end{tabular}

Notes on forest cover definitions and adjustments to study region: 1. Landsat Pathfinder [22]. Forests = closed canopy forests. The Landsat Pathfinder estimate of forest cover for year 1988 for Brazilian Amazon is corrected for loss of forests from INPE deforestation estimates for period 1988-2000 [7]; 2. FAO FRA 2000 RSS [11]. We use the second definition (f2) which "was constructed to match the forest definition used in the country reporting". Forests = closed canopy forests (canopy cover $>40 \%$ ) + Open canopy forests (canopy cover 10-40\%) + a fraction (two-ninths) of the fragmented forests (mosaic of forest/non-forest). We subtracted the forest area of Mexico from FRA 2010 country survey; 
3. TREES-II [4]. Forests = closed evergreen and seasonal forests of the tropical humid bioclimatic zone. Adjustment to Central and South America region: we used the forest cover estimate of Latin America for year 1997; this estimate was corrected to year 2000 by using TREES-II annual deforestation rate; we then subtracted the forest area of Mexico from FAO FRA 2010 country survey and added areas of tropical dry forests of South America from GLC-2000. Adjustment to Legal Amazon region region: we used the forest cover estimate of "Brazilian Amazon and Guyanas" region. We subtracted the forest area of Guianas from FAO FRA-2010 country survey; 4. SDSU (South Dakota State University) [5]. Forests were defined as $>25 \%$ canopy cover. We considered the SDSU forest area estimate of year 2000 for South America. We added forest area of Central America and subtracted forest areas of Argentina, Chile and Uruguay from FAO FRA 2010 country survey; 5. FAO FRA 2010 Country Survey (CS) [6]. Forest = Land spanning more than 0.5 hectares with trees higher than 5 meters and a canopy cover $>10 \%$; it does not include land that is predominantly under agriculture use. We considered the sum of forest area estimates of year 2000 for Central America and South America and subtracted forest areas of Argentina, Chile and Uruguay.

Land cover change matrices were produced at three geographical levels: for the whole study area (Table 2), for Brazil and for the Brazilian Legal Amazon and again compare them to other studies (Table 3). Between 1990 and 2000 there was a net loss in the whole study area of $2.98 \mathrm{Mha}^{-1}$ (s.e. $0.26 \mathrm{Mha}^{-1} \mathrm{y}^{-1}$ ) of forests rising to $3.74 \mathrm{Mha} \cdot \mathrm{y}^{-1}$ (s.e. $0.39 \mathrm{Mha} \cdot \mathrm{y}^{-1}$ ) in the 2000 to 2005 period

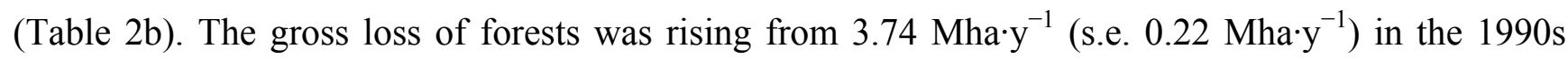
( $0.50 \%$ annually) to $4.40 \mathrm{Mha}^{-1} \mathrm{y}^{-1}$ (s.e. $0.32 \mathrm{Mha} \cdot \mathrm{y}^{-1}$ ) in the 2000 to 2005 period $(0.61 \%$ annually), with Brazil accounting for $69 \%$ of the total. The increase in the gross loss of other wooded land was

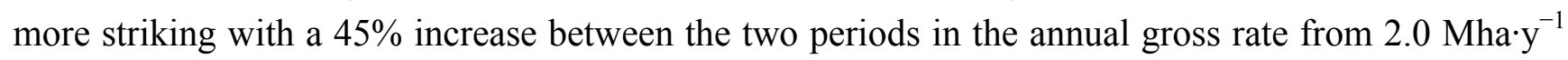
(s.e. $0.11 \mathrm{Mha} \cdot \mathrm{y}^{-1}$ ) in the $1990 \mathrm{~s}$ to $2.9 \mathrm{Mha} \cdot \mathrm{y}^{-1}$ (s.e. $0.37 \mathrm{Mha} \cdot \mathrm{y}^{-1}$ ) in the early $2000 \mathrm{~s}$. In both periods circa $60 \%$ of the cleared forests were converted to other land cover (this proportion is circa $68 \%$ for Brazilian Legal Amazon). The main area of forest loss in both periods was in the so called 'arc of deforestation' in the Brazilian Amazon (55\% and 58\% of the total for the 1990s and early 2000s respectively) (Figure 4), whereas changes in other wooded land were geographically more widespread, with high losses occurring in the Brazilian states of Mato Grosso and Tocantins. Large non-forest areas were also re-occupied by forests. Forest regrowth (defined as the gross gain of forests) decreased slightly from $0.65 \mathrm{Mha} \cdot \mathrm{y}^{-1}$ (s.e. $0.08 \mathrm{Mha}^{-1}{ }^{-1}$ ) in the 1990 s to $0.46 \mathrm{Mha}^{-1}{ }^{-1}$ (s.e. $0.04 \mathrm{Mha}^{-1}{ }^{-1}$ ) in the early 2000s. During the first period the continent was losing more than $5.7 \mathrm{Mha} \cdot \mathrm{y}^{-1}$ of forests and other wooded lands a year (gross loss) rising to over $7.3 \mathrm{Mha}^{-1}$ in the second period, while re-colonization of these areas fell from 2.6 Mha $\mathrm{y}^{-1}$ to $2.5 \mathrm{Mha} \cdot \mathrm{y}^{-1}$ between the periods. Our gross annual deforestation rate for the period 2000-2005 corresponds closely to those of South Dakota State University (SDSU) for both Brazil and for the continent (Table 4). Both our study and that of SDSU give higher figures (from $12 \%$ to $18 \%$ ) than the official ones provided by the Brazilian National Space Agency (INPE-Instituto Nacional De Pesquisas Espaciais) for the Legal Amazon [12]. These differences seem to be due to cerrado clearance which is not accounted for in INPE's official figures [39].

The spatial distribution of forest change is highly concentrated in the study area, (Figure 4), highlighting the need for spatially explicit data on biomass. 
Table 4. Annual tropical forest cover change estimates for periods 1990-2000 and 2000-2005 for (i) South \& Central America region; (ii) Brazil; (iii) Brazilian Amazon from different sources-from oldest to most recent publication date (in $10^{6} \mathrm{ha} / \mathrm{year}$ )

\begin{tabular}{|c|c|c|c|c|c|}
\hline $\begin{array}{l}\text { Source } \\
\text { Region }\end{array}$ & INPE $^{1}$ & $\begin{array}{c}\text { FAO } \\
\text { FRA-2000 RSS }^{2}\end{array}$ & SDSU & $\begin{array}{c}\text { FAO } \\
\text { FRA-2010 CS }\end{array}$ & This Study \\
\hline \multicolumn{6}{|c|}{ Gross annual forest loss } \\
\hline Tropical America 1990-2000 & & 4.05 & & & $3.74(\mathrm{se} 0.22)$ \\
\hline Tropical America 2000-2005 & & & 4.3 & & $4.40($ se 0.32$)$ \\
\hline Brazil 1990-2000 & & & & & $2.59($ se 0.35$)$ \\
\hline Brazil 2000-2005 & & & 3.3 & & $3.02(\mathrm{se} 0.25)$ \\
\hline Legal Amazon 1990-2000 & 1.68 & & & & $2.07($ se 0.35$)$ \\
\hline Legal Amazon 2000-2005 & 2.24 & & 2.6 & & $2.55($ se 0.26$)$ \\
\hline \multicolumn{6}{|c|}{ Net annual forest cover changes } \\
\hline Tropical America 1990-2000 & & 3.85 & & 4.19 & $2.98(\mathrm{se} 0.26)$ \\
\hline Tropical America 2000-2005 & & & & 4.34 & $3.74($ se 0.39$)$ \\
\hline Brazil 1990-2000 & & & & 2.89 & $2.09(\mathrm{se} 0.36)$ \\
\hline Brazil 2000-2005 & & & & 3.09 & $2.57(\mathrm{se} 0.31)$ \\
\hline
\end{tabular}

Notes: 1. INPE deforestation estimates for Brazilian Legal Amazon [12] considers only humid forests.

2. FAO FRA 2000 RSS annual deforestation [11] is corrected for Mexico from FAO FRA-2010 CS.

Figure 4. Maps of results obtained for all sample sites: (a) forest cover proportions for year 2000 (range: from 0 to 1); (b) proportions of gross forest loss from 1990 to 2000; (c) proportions of gross forest loss from 2000 to 2005 .

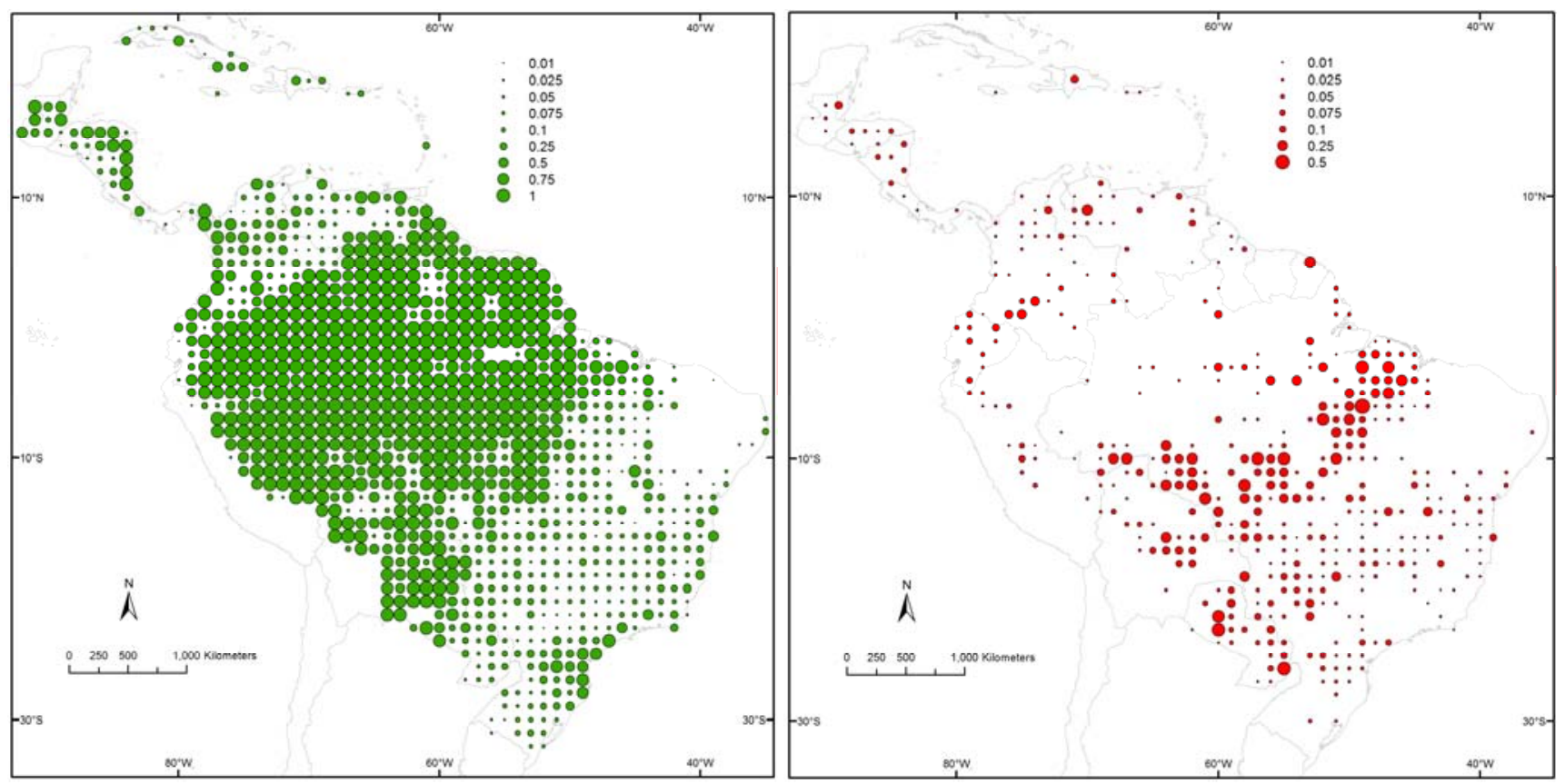

(a)

(b) 
Figure 4. Cont.

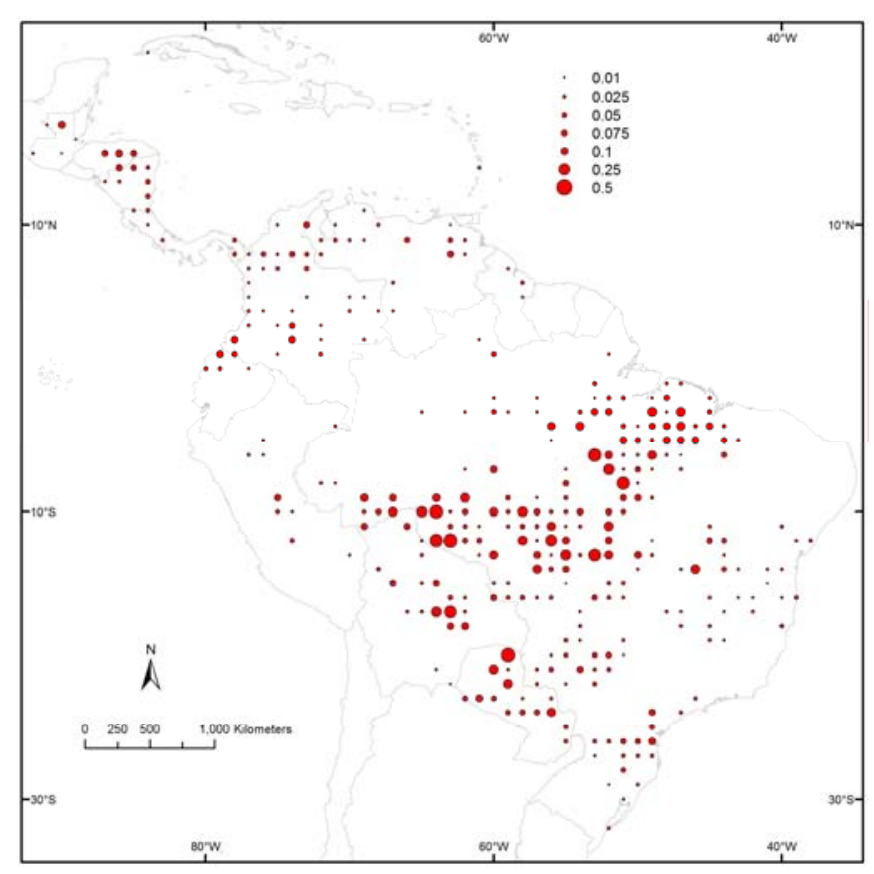

(c)

\subsection{Emissions Estimates Results}

We calculated the emissions resulting from changes in forest and other wooded land at three geographical levels, for the whole study area (Figure 5), for Brazil and for the Brazilian Legal Amazon and compare them to other estimates (Table 5). The annual carbon flux (10 year committed emissions) for the whole study area results in $482 \mathrm{MtC} \cdot \mathrm{y}^{-1}$ for the $1990 \mathrm{~s}$ is close to our previous estimate at $519 \mathrm{MtC} \cdot \mathrm{y}^{-1}$, and rises to $583 \mathrm{MtC} \cdot \mathrm{y}^{-1}$ for the first half of the $2000 \mathrm{~s}$, reflecting the increase in deforestation in the latter period. For Brazil alone our estimate of the annual carbon flux for the 1990s is $351 \mathrm{MtC} \cdot \mathrm{y}^{-1}\left(888 \mathrm{MtCO}_{2} \cdot \mathrm{y}^{-1}\right)$ as 10 year committed emissions or $508 \mathrm{MtC} \cdot \mathrm{y}^{-1}\left(1287 \mathrm{MtCO}_{2} \cdot \mathrm{y}^{-1}\right)$ as potential long-term emissions (i.e., if all carbon from one year of deforestation and woodland clearance would go into the atmosphere). Similarly for the 2000-2005 period our estimates of emissions are $423 \mathrm{MtC} \cdot \mathrm{y}^{-1}\left(1,070 \mathrm{MtCO}_{2} \cdot \mathrm{y}^{-1}\right)$ as 10 year committed emissions or $613 \mathrm{MtC} \cdot \mathrm{y}^{-1}\left(1,551 \mathrm{MtCO}_{2} \cdot \mathrm{y}^{-1}\right)$ as potential long-term emissions. Our results can be compared to figures reported by Brazil to the UNFCC [40,41]: the annual net anthropogenic $\mathrm{CO}_{2}$ emissions from the Land-use Change and Forestry sector are reported in Brazil's second communication at 761, 821, 1,249 and 1,251 $\mathrm{MtCO}_{2} \cdot \mathrm{y}^{-1}$ for the accounting years 1990, 1994, 2000 and 2005 respectively [40]. Brazil's first national communication provided earlier estimates giving details of four different components: sources from "Forest and Grassland conversions" and from "Emissions and Removals from Soils" and Sinks from "Changes in Forest and Other Woody Biomass Stocks" and from "Abandonment of Managed Land" [41]. For the year 1990 the sources were reported as $882 \mathrm{MtCO}_{2} \cdot \mathrm{y}^{-1}$ and $110 \mathrm{MtCO}_{2} \cdot \mathrm{y}^{-1}$ from Land Use conversions and from Soils respectively and the total sinks were reported at $234 \mathrm{MtCO}_{2} \cdot \mathrm{y}^{-1}$, when for the year 2005 the sources were $1026 \mathrm{MtCO}_{2} \cdot \mathrm{y}^{-1}$ and $65 \mathrm{MtCO}_{2} \cdot \mathrm{y}^{-1}$ and the total sinks were $230 \mathrm{MtCO}_{2} \cdot \mathrm{y}^{-1}$. If we consider our estimate of forest regrowth areas at the end of the period 1990-2000 (i.e., total of areas which have been reconverted to forests during the 10 year period) at 7.6 Mha (s.e. 0.67 Mha), and by using the rates of annual carbon gains in secondary vegetation used by Brazil in their national report 
$\left(6.2 \mathrm{tC} \cdot \mathrm{ha}^{-1}\right.$ for forest with biomass higher than $127 \mathrm{tC} \cdot \mathrm{ha}^{-1}$ and $5.1 \mathrm{tC} \cdot \mathrm{ha}^{-1}$ for less than $127 \mathrm{tC} \cdot \mathrm{ha}^{-1}$ ) we obtain a yearly sink of $168 \mathrm{MtCO}_{2} \cdot \mathrm{y}^{-1}$ for these regrowing forests accumulated during that 10 -year period for all tropical South America. If we make the hypothesis that there have been similar rates of re-conversion to forests during the $1975-1990$ period, a value of $336 \mathrm{MtCO}_{2} \cdot \mathrm{y}^{-1}$ corresponding to sinks from 20 years of accumulated regrowth can be considered as a conservative (i.e., maximum) estimate for annual removals during the study period of carbon from forest regrowth. The Brazilian estimate of $240 \mathrm{MtCO}_{2} \cdot \mathrm{y}^{-1}$ (average of years 1990, 1994 and 2005) which includes two components: sinks from changes in forest biomass stocks and sinks from abandonment of managed land, corresponds to $70 \%$ of this.

Figure 5. Maps of emissions resulting from changes in forest and other wooded land cover for all sample sites: (a) carbon content for forest ecosystems; (b) emissions from 1990 to 2000; (c) emissions from 2000 to 2005. Emissions from deforestation displayed as brown discs, emissions from loss of other wooded land as red circles. Values in $\mathrm{tC} \cdot \mathrm{ha}^{-1}$.

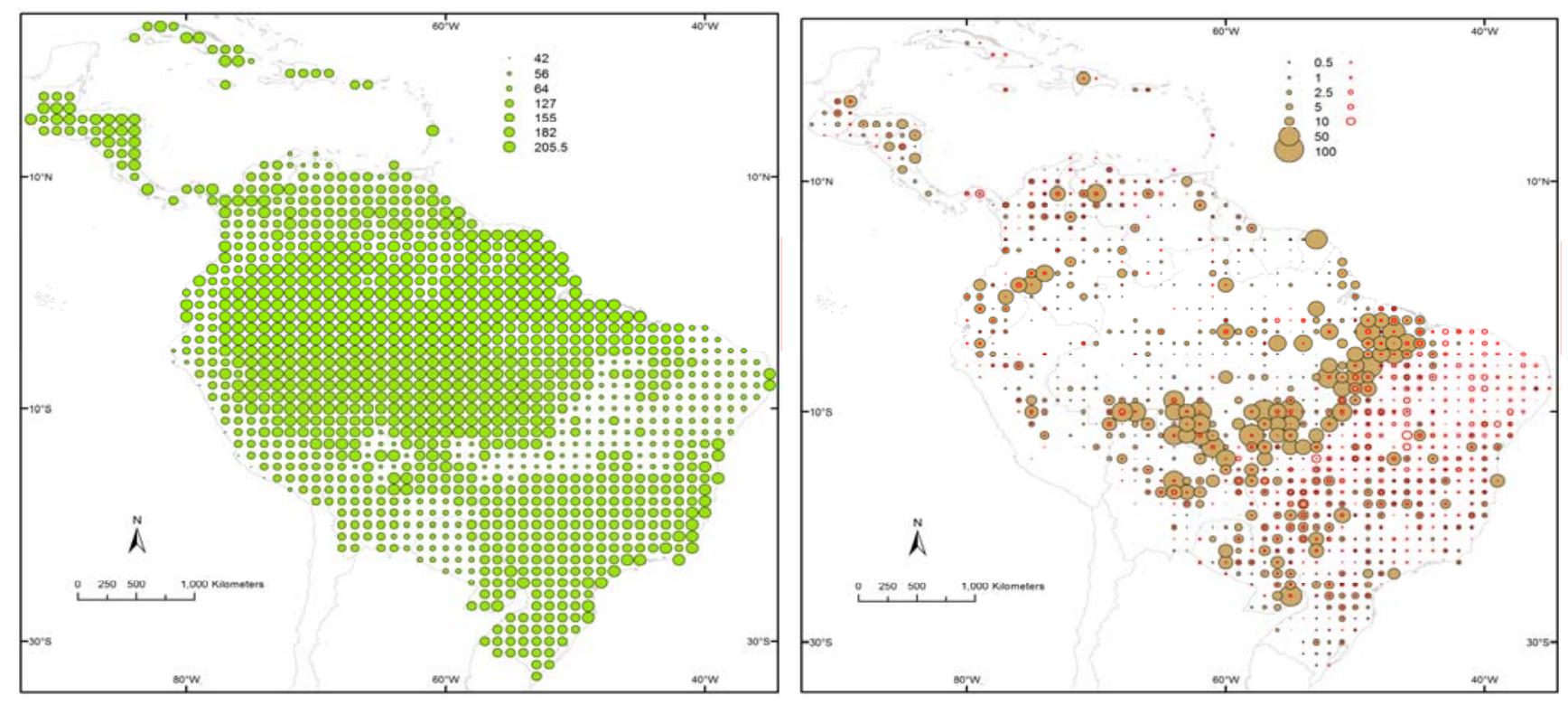

(a)

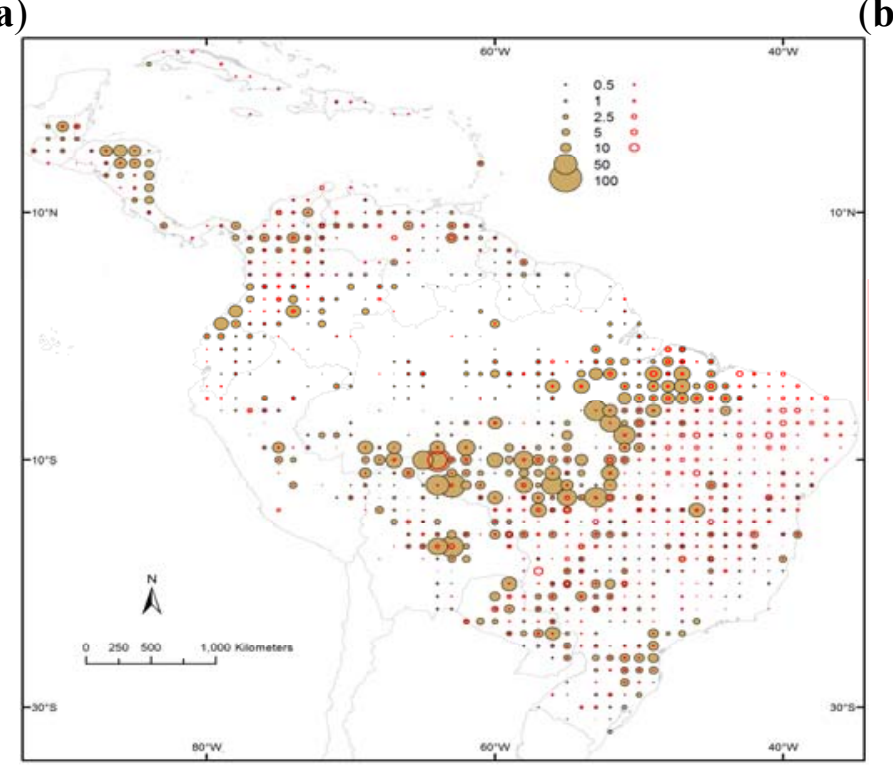

(b)

(c) 
The national figures reported by Brazil in the second communication to the UNFCCC correspond to net emissions of carbon emissions, i.e., with removals of carbon in managed areas and carbon gains in secondary vegetation areas, which explains why such figures are lower than our potential long-term emission estimates. However, the different contributions-sources from deforestation, removals in managed areas and in secondary vegetation - are not reported individually by Brazil. The Brazilian national figures include also carbon emissions from soils but the first national communication shows that emissions from soils represent a limited contribution, i.e., circa 7\% of the emissions from land use conversions. On the other hand the Brazilian report does not seem to consider a decay model for distributing emissions over time, i.e., emissions factors are used as yearly direct emissions. This explains why the Brazilian estimates of net emissions are higher than our 10-year committed emission estimates.

The consequences of these land cover changes are multiple. The comparison of our results for emissions with the Brazilian national figures shows that the potential gross emissions from forest and woodland clearance are much higher than the net emissions reported in national reports. Our results show the importance of emissions from forest and woodland clearance in tropical America and the need to consider carefully what is accounted for when reporting emissions and removals from anthropogenic processes.

Table 5. Annual carbon emissions from tropical forest cover changes for periods 1990-2000 and 2000-2005 for (i) South \& Central America region; (ii) Brazil; (iii) Brazilian Amazon from different sources - from oldest to most recent publication date (in $10^{6}$ ty $^{-1}$ ).

\begin{tabular}{|c|c|c|c|c|c|c|c|}
\hline $\begin{array}{c}\text { Source of Estimate } \\
\text { Carbon } \\
\text { Emissions/Loss }\end{array}$ & $\begin{array}{l}\text { TREES-II } \\
1990-1997\end{array}$ & $\begin{array}{c}\text { Brazil 1 }^{\text {st }} \\
\text { National } \\
\text { Communication }\end{array}$ & $\begin{array}{c}\text { Brazil } 2^{\text {nd }} \\
\text { National } \\
\text { Communication }\end{array}$ & $\begin{array}{c}\text { FAO } \\
\text { FRA- } \\
2010 \text { CS }\end{array}$ & $\begin{array}{c}\text { Pan } e t \\
a l .2011 \\
{[2]}\end{array}$ & $\begin{array}{l}\text { This Study } \\
10 \text { Year } \\
\text { Committed }\end{array}$ & $\begin{array}{l}\text { This Study } \\
\text { Total } \\
\text { Carbon Loss }\end{array}$ \\
\hline \multicolumn{8}{|l|}{$\begin{array}{l}\text { Annual } \mathrm{C} \text { emissions } \\
\qquad\left(10^{6} \mathrm{tC} \cdot \mathrm{y}^{-1}\right)\end{array}$} \\
\hline $\begin{array}{l}\text { Tropical America } \\
1990-2000\end{array}$ & 519 & & & & 1510 & 482 & 698 \\
\hline $\begin{array}{l}\text { Tropical America } \\
\text { 2000-2005 }\end{array}$ & & & & & 1370 & 583 & 845 \\
\hline Brazil 1990-2000 & & & & 282 & & 351 & \\
\hline Brazil 2000-2005 & & & & 325 & & 423 & \\
\hline $\begin{array}{l}\text { Legal Amazon } \\
\text { 1990-2000 }\end{array}$ & 260 & & & & & 277 & \\
\hline $\begin{array}{l}\text { Legal Amazon } \\
\text { 2000-2005 }\end{array}$ & & & & & & 350 & \\
\hline \multicolumn{8}{|l|}{$\begin{array}{l}\text { Annual } \mathrm{CO}_{2} \text { emissions } \\
\qquad\left(10^{6} \mathrm{tCO}_{2} \cdot \mathrm{y}^{-1}\right)\end{array}$} \\
\hline Brazil 1990-2000 & & 997 & 944 & & & 888 & 1,287 \\
\hline Brazil 2000-2005 & & 1,081 & 1,250 & & & 1,070 & 1,551 \\
\hline $\begin{array}{l}\text { Legal Amazon } \\
1990-2000\end{array}$ & & & 599 & & & 700 & 1,015 \\
\hline $\begin{array}{l}\text { Legal Amazon } \\
2000-2005\end{array}$ & & & 829 & & & 885 & 1,282 \\
\hline
\end{tabular}

Notes: 1. TREES-II estimates [35] are committed 'maximum' emissions over 10 year period; 2. First and second national communications from Brazil to UNFCCC [40,41] are reporting net emissions for years 1990, 1994, 2000 and 2005. Estimates for periods 1990-2000 and 2000-2005 are calculated as average of figures of years 1990, 1994 and 2000 and average of figures of years 2000 and 2005 respectively; 3. FAO FRA 2010 country Survey [6] is corresponding to "annual change in carbon stocks in living forest biomass". 
The more recent study on the role of the world's forest in the carbon cycle [2] reports gross deforestation emission in South America at 1.51 and $1.37 \mathrm{Pg} \cdot \mathrm{C} \cdot \mathrm{y}^{-1}$ for the $1990 \mathrm{~s}$ and $2000 \mathrm{~s}$ (2000-2007 period) respectively which are around twice as high as our estimates of potential long-term emissions (i.e., full carbon loss) at 0.70 and $0.84 \mathrm{Pg} \cdot \mathrm{C} \cdot \mathrm{y}^{-1}$ for the $1990 \mathrm{~s}$ and early $2000 \mathrm{~s}$ (2000-2005 period) respectively, and circa three times higher than our estimates of 10 year committed emissions at 0.48 and $0.58 \mathrm{Pg} \cdot \mathrm{C} \cdot \mathrm{y}^{-1}$ for the $1990 \mathrm{~s}$ and early $2000 \mathrm{~s}$ (2000-2005 period) respectively. These high estimates for gross carbon emissions from tropical deforestation are based on FAO national statistics with their known limitations [1]. The same study also reports on sinks from tropical regrowth in South America giving 0.81 and $0.83 \mathrm{Pg} \cdot \mathrm{C} \cdot \mathrm{y}^{-1}$ for the $1990 \mathrm{~s}$ and $2000 \mathrm{~s}$ which compare to the Brazilian estimate from first communication at $0.065 \mathrm{Pg} \cdot \mathrm{C} \cdot \mathrm{y}^{-1}$ (average of years 1990, 1994, 2000 and 2005) and our own estimate for tropical South America at $0.092 \mathrm{Pg} \cdot \mathrm{C} \cdot \mathrm{y}^{-1}$ for the $1990 \mathrm{~s}$. If Brazil were to use the same rate of annual carbon gains in secondary vegetation as the global study (i.e., $3.8 \mathrm{tC} \cdot \mathrm{ha}^{-1}$ ) the Brazilian estimate of sinks would be even smaller. This indicates another high discrepancy between the results of [2] and the estimates from robust bottom-up approaches. Our consistent approach based on remote sensing for forest (and other woodland ecosystems) area and forest area change estimation combined with spatial information on the distribution of biomass in forests provide a more direct and robust approach for producing estimates of carbon emissions from land cover changes in tropical South America.

\section{Conclusions}

We developed a method for producing repeatable estimates of forest and woodland change and the resulting carbon fluxes for tropical South America, based on the analysis of medium resolution satellite data. Each step of the process from the sampling design, through image selection, pre-processing and classification has been the result of careful in-house research [18,21,22,24]. This work is important in the context of developing methods for providing consistent repeatable and accurate data for initiatives such as REDD, where payments will be issued on the basis of verifiable reductions in emissions due to deforestation. Unlike many previous continental scale studies our estimates use spatially specific data for both forest change and for biomass. We found that an extensive investment in expert control of the data was required so as to ensure the consistency and quality of the forest change maps produced by the automatic classification. This points to the need for caution when relying solely on automated process chains.

The results show that tropical South America has been losing $5.7 \mathrm{Mha} \cdot \mathrm{y}^{-1}$ of forests and other wooded land a year in the 1990 s rising to over $7.3 \mathrm{Mha}^{-1} \mathrm{y}^{-1}$ in the 200-2005 period. The ensuing annual carbon emissions from these losses amount to $482 \mathrm{MtC} \cdot \mathrm{y}^{-1}$ and $583 \mathrm{MtC} \cdot \mathrm{y}^{-1}$ respectively for the two periods. The loss of other wooded land, while less significant in terms of emissions, is nevertheless extensive (over $30 \%$ of the total) and of concern for biodiversity. Our results are consistent with those produced from satellite data at the national level by Brazil, but are at odds with a recent estimation [2] based on FAO country statistics.

The main errors in our estimates come from continued uncertainty in forest and woodland biomass at continental levels and in the accurate determination of forest area and area change in fragmented landscapes. The assessment of these errors is an issue which requires further research and quantification as many national forest assessments are turning to this type of remote sensing data for 
their reporting. However, the capacity to determine the accuracy of such measurements across large areas is improving, given wider access to very high resolution data [42].

The future priorities for the production of more accurate and precise estimates of carbon emissions from tropical deforestation should therefore be to improve regional forest inventories by assessing carbon content (density) and emissions at local scale and possibly with the use of remote sensing technology for remote areas [43].

The land monitoring described here in this study will be expanded to the tropics to allow a global-scale aggregation.

\section{Acknowledgments}

We acknowledge the contribution of scientific and technical staff from JRC and EMBRAPA, in particular Catherine Bodart, Rastislav Raši, Dario Simonetti and Hans-Jürgen Stibig from JRC for the development of the processing tools, Desirée Johansson from JRC for the data selection, Catherine Bodart and Ouns Kissiyar from JRC for the participation to the satellite imagery interpretation, staff from EMBRAPA-CNPM for the initial interpretation of satellite imagery over Brazil, María A. Oliveira-Miranda from the Centro de Ecologia of the Instituto Venezolano de Investigaciones Ceintificas (IVIC) and Otto Huber for the initial interpretation of satellite imagery over Venezuela, Armando Rodriguez Montellano from Fundacion Amigos de la Naturaleza (FAN) for the initial interpretation of satellite imagery over Bolivia. We thank Dalton de Morisson Valeriano of INPE for organizing the cross-validation exercise.

\section{References}

1. Grainger, A. Difficulties in tracking the long-term global trend in tropical forest area. Proc. Natl. Acad. Sci. USA 2008, 105, 818-823.

2. Pan, Y.; Birdsey, R.A.; Fang, J.; Houghton, R.; Kauppi, P.E.; Kurz, W.A.; Phillips, O.L.; Shvidenko, A.; Lewis, S.L.; Canadell, J.G.; et al. A large and persistent carbon sink in the world's forests. Science 2011, 333, 988-993.

3. Achard, F.; Eva, H.D.; Stibig, H.J.; Mayaux, P.; Gallego, J.; Richards, T.; Malingreau, J.P. Determination of deforestation rates of the world's humid tropical forests. Science 2002, 297, 999-1002.

4. Hansen, M.C.; Stehman, S.V.; Potapov, P.V.; Loveland, T.R.; Townshend, J.R.G.; DeFries, R.S.; Pittman, K.W.; Arunarwati, B.; Stolle, F.; Steininger, M.K.; et al. Humid tropical forest clearing from 2000 to 2005 quantified by using multitemporal and multiresolution remotely sensed data. Proc. Natl. Acad. Sci. USA 2008, 105, 9439-9444.

5. Gibbs, H.K.; Ruesch, A.S.; Achard, F.; Clayton, M.K.; Holmgren, P.; Ramankutty, N.; Foley, J.A. Tropical forests were the primary sources of new agricultural land in the 1980s and 1990s. Proc. Natl. Acad. Sci. USA 2010, 107, 16732-16737.

6. FAO. Global Forest Assessment 2010: Main Report; Food and Agriculture Organization of the UN: Rome, Italy, 2010; p. 378. 
7. Mollicone, D.; Achard, F.; Federici, S.; Eva, H.D.; Grassi, G.; Belward, A.; Raes, F.; Seufert, G.; Stibig, H.J.; Matteucci, G.; et al. An incentive mechanism for reducing emissions from conversion of intact and non-intact forests. Climate Change 2007, 83, 477-493.

8. Grassi, G.; Monni, S.; Federici, S.; Achard, F.; Mollicone, D. Applying the conservativeness principle to REDD to deal with the uncertainties of the estimates. Environ. Res. Lett. 2008, 3, 035005.

9. GOFC-GOLD. A Sourcebook of Methods and Procedures for Monitoring and Reporting Anthropogenic Greenhouse Gas Emissions and Removals Caused by Deforestation, Gains and Losses of Carbon Stocks in Forests Remaining Forests, and Forestation; GOFC-GOLD GOFC-GOLD Project Office, Natural Resources Canada: Calgary, AB, Canada, 2010; p. 210.

10. Duveiller, G.; Defourny, P.; Desclée, B.; Mayaux, P. Deforestation in Central Africa: Estimates at regional, national and landscape levels by advanced processing of systematically-distributed Landsat extracts. Remote Sens. Environ. 2008, 112, 1969-1981.

11. FAO; JRC; SDSU; ULC. The 2010 Global Forest Resources Assessment Remote Sensing Survey: An Outline of the Objectives, Data, Methods and Approach; FAO: Rome, Italy, 2009.

12. INPE. Monitoramento da Floresta Amazonica Brasileira por Satelite. Available online: http://www.obt.inpe.br/prodes/index.html (accessed on 5 November 2011).

13. Pelletier, J.; Ramankutty, N.; Potvin, C. Diagnosing the uncertainty and detectability of emission reductions for REDD + under current capabilities: An example for Panama. Environ. Res. Lett. 2011, 6, 024005.

14. McRoberts, R.; Tomppo, E. Remote sensing support for national forest inventories. Remote Sens. Environ. 2007, 110, 412-419.

15. Achard, F.; Stibig, H.J.; Eva, H.D.; Lindquist, E.J.; Bouvet, A.; Arino, O.; Mayaux, P. Estimating tropical deforestation from Earth observation data. Carbon Manage. 2010, 1, 271-287.

16. Arai, E.; Shimabukuro, Y.E.; Pereira, G.; Vijaykumar, N.L. A multi-resolution multi-temporal technique for detecting and mapping deforestation in the Brazilian amazon rainforest. Remote Sens. 2011, 3, 1943-1956.

17. Mayaux, P.; Holmgren, P.; Achard, F.; Eva, H.; Stibig, H.J.; Branthomme, A. Tropical forest cover change in the $1990 \mathrm{~s}$ and options for future monitoring. Philos. Trans. R. Soc. B: Biol. Sci. 2005, 360, 373-384.

18. Eva, H.; Carboni, S.; Achard, F.; Stach, N.; Durieux, L.; Faure, J.-F.; Mollicone, D. Monitoring forest areas from continental to territorial levels using a sample of medium spatial resolution satellite imagery. ISPRS J. Photogramm. 2010, 65, 191-197.

19. Stehman, S.V. Comparing estimators of gross change derived from complete coverage mapping versus statistical sampling of remotely sensed data. Remote Sens. Environ. 2005, 96, 466-474.

20. Tucker, C.J.; Grant, D.M.; Dykstra, J.D. NASA's global orthorectified landsat data set. Photogramm. Eng. Remote Sensing 2004, 70, 313-332.

21. Beuchle, R.; Eva, H.D.; Stibig, H.J.; Bodart, C.; Brink, A.; Mayaux, P.; Johansson, D.; Achard, F.; Belward, A. A satellite data set for tropical forest area change assessment. Int. J. Remote Sens. 2011, 32, 7009-7031. 
22. Bodart, C.; Eva, H.; Beuchle, R.; Raši, R.; Simonetti, D.; Stibig, H.J.; Brink, A.; Lindquist, E.; Achard, F. Pre-processing of a sample of multi-scene and multi-date Landsat imagery used to monitor forest cover changes over the tropics. ISPRS J. Photogramm. 2011, 66, 555-563.

23. Hansen, M.C.; Roy, D.P.; Lindquist, E.; Adusei, B.; Justice, C.O.; Altstatt, A. A method for integrating MODIS and Landsat data for systematic monitoring of forest cover and change in the Congo Basin. Remote Sens. Environ. 2008, 112, 2495-2513.

24. Raši, R.; Bodart, C.; Stibig, H.J.; Eva, H.; Beuchle, R.; Carboni, S.; Simonetti, D.; Achard, F. An automated approach for segmenting and classifying a large sample of multi-date Landsat imagery for pan-tropical forest monitoring. Remote Sens. Environ. 2011, 115, 3659-3669.

25. Särndal, C.E.; Swensson, B.; Wretman, J. Model Assisted Survey Sampling; Springer-Verlag: New York, NY, USA, 1992.

26. Stehman, S.V.; Hansen, M.C.; Broich, M.; Potapov, P.V. Adapting a global stratified random sample for regional estimation of forest cover change derived from satellite imagery. Remote Sens. Environ. 2011, 115, 650-658.

27. Foody, G.M. Assessing the accuracy of land cover change with imperfect ground reference data. Remote Sens. Environ. 2010, 114, 2271-2285.

28. Gibbs, H.K.; Brown, S.; Niles, J.O.; Foley, J.A. Monitoring and estimating tropical forest carbon stocks: Making REDD a reality. Environ. Res. Lett. 2007, 2, 13 pp.

29. Eva, H.D.; Achard, F.; Stibig, H.-J.; Mayaux, P. Response to comment on "determination of deforestation rates of the world's humid tropical forests". Science 2003, 299, 1015.

30. Malhi, Y.; Wood, D.; Baker, T.R.; Wright, J.; Phillips, O.L.; Cochrane, T.; Meir, P.; Chave, J.; Almeida, S.; Arroyo, L.; et al. The regional variation of aboveground live biomass in old-growth Amazonian forests. Glob. Chang. Biol. 2006, 12, 1107-1138.

31. Nogueira, E.M.; Fearnside, P.M.; Nelson, B.W.; Barbosa, R.I.; Keizer, E.W.H. Estimates of forest biomass in the Brazilian Amazon: New allometric equations and adjustments to biomass from wood-volume inventories. For. Ecol. Manage. 2008, 256, 1853-1867.

32. Asner, G.P.; Powell, G.V.N.; Mascaro, J.; Knapp, D.E.; Clark, J.K.; Jacobson, J.; Kennedy-Bowdoin, T.; Balaji, A.; Paez-Acosta, G.; Victoria, E.; et al. High-resolution forest carbon stocks and emissions in the Amazon. Proc. Natl. Acad. Sci. USA 2010, 107, 16738-16742.

33. IPCC. IPCC Guidelines for National Greenhouse Gas Inventories; IPCC National GHG Inventories Programme: Hayama, Japan, 2006.

34. Ramankutty, N.; Gibbs, H.K.; Achard, F.; Defries, R.; Foley, J.A.; Houghton, R.A. Challenges to estimating carbon emissions from tropical deforestation. Glob. Chang. Biol. 2007, 13, 51-66.

35. Achard, F.; Eva, H.D.; Mayaux, P.; Stibig, H.J.; Belward, A. Improved estimates of net carbon emissions from land cover change in the tropics for the 1990s. Glob. Biogeochem. Cycl. 2004, 18, GB2008 1-11.

36. Eva, H.D.; Belward, A.S.; de Miranda, E.E.; Di Bella, C.M.; Gond, V.; Huber, O.; Jones, S.; Sgrenzaroli, M.; Fritz, S. A land cover map of South America. Glob. Chang. Biol. 2004, 10, 731-744.

37. FAO. Global Forest Resources Assessment 2000; FAO: Rome, Italy, 2001.

38. Skole, D.; Tucker, C. Tropical deforestation and habitat fragmentation in the amazon: Satellite data from 1978 to 1988. Science 1993, 260, 1905-1910. 
39. Hansen, M.C.; Shimabukuro, Y.E.; Potapov, P.; Pittman, K. Comparing annual MODIS and PRODES forest cover change data for advancing monitoring of Brazilian forest cover. Remote Sens. Environ. 2008, 112, 3784-3793.

40. Brazil Second National Communication of Brazil to the United Nations Framework Convention on Climate Change. Available online: http://www.mct.gov.br/index.php/content/view/326984.html (accessed on 25 July 2011).

41. Cerri, C.C.; Maia, S.M.F.; Galdos, M.V.; Cerri, C.E.P.; Feigl, B.J.; Bernoux, M. Brazilian greenhouse gas emissions: The importance of agriculture and livestock. Sci. Agric. 2009, 66, 831-843.

42. Dorais, A.; Cardille, J. Strategies for incorporating high-resolution google earth databases to guide and validate classifications: Understanding deforestation in Borneo. Remote Sens. 2011, 3, 1157-1176.

43. Goetz, S.; Dubayah, R. Advances in remote sensing technology and implications for measuring and monitoring forest carbon stocks and change. Carbon Manage. 2011, 2, 231-244.

(C) 2012 by the authors; licensee MDPI, Basel, Switzerland. This article is an open access article distributed under the terms and conditions of the Creative Commons Attribution license (http://creativecommons.org/licenses/by/3.0/). 